\title{
A MULTI-PROXY LAKE SEDIMENT RECORD OF INDIAN SUMMER MONSOON VARIABILITY DURING THE HOLOCENE IN SOUTHERN INDIA
}

K. Sandeep ${ }^{1, \#, *}$, R. Shankar ${ }^{1}$, Anish Kumar Warrier ${ }^{1, \&}$, M.G. Yadava ${ }^{2}$, R. Ramesh ${ }^{2,3}$, R.A. Jani $^{2}$, Z. Weijian ${ }^{4}$ and Lu Xuefeng ${ }^{4}$

${ }^{1}$ Department of Marine Geology, Mangalore University, Mangalagangotri-574 199, India

${ }^{2}$ Physical Research Laboratory, Navrangpura, Ahmedabad, Gujarat-380009, India

${ }^{3}$ Present address: School of Earth and Planetary Sciences, National Institute of Science Education and Research, P.O. Jatni, Khurda, Odisha - 752050, India

${ }^{4}$ Xi' an AMS Center, Institute of Earth Environment, Xi'an, China

"Present address: Department of Geology, School of Earth Science Systems, Central University of Kerala, Periye (P.O.), Tejaswini Hills, Kasaragod, Kerala-671316, India

${ }^{\&}$ Present address: Department of Civil Engineering, Manipal Institute of Technology, Manipal University, Manipal, Karnataka-576104, India

*Correspondence to: sandeepk01@gmail.com 


\section{Abstract}

We present here a 11,000-year palaeomonsoonal record from a sediment core (SS-1) from Shantisagara (SS) Lake in Peninsular India, which is the longest published so far from the region. This is also a region with limited palaeoclimate records. Environmental magnetic, organic geochemical, sedimentological and carbon isotopic studies were carried out on the SS-1 sediments to reconstruct the Indian summer monsoon (ISM) variability during the Holocene. The chronology of the sediments is constrained by three AMS ${ }^{14} \mathrm{C}$ dates. Environmental magnetic data reveal that there is no contribution from bacterial magnetite, greigite and anthropogenic magnetite/lithogenic grains and that the magnetic signal is contributed mainly by the pedogenic component. The environmental magnetic data also depict variations in pedogenic magnetite production in the catchment and detrital influx to the lake, which in turn is related to monsoonal rainfall amount. The sedimentological data reveal variations in sediment size related to monsoon. The $\mathrm{C}_{\text {org }} / \mathrm{N}$ ratio and $\delta^{13} \mathrm{C}$ indicate palaeovegetational variations in the SS catchment. Periods of strong monsoon are characterised by high values of concentration-dependent magnetic parameters like $\chi_{\mathrm{lf}}, \chi_{\mathrm{fd}}$, $\chi_{\mathrm{ARM}}$ and SIRM, high sand content, low $\mathrm{C}_{\mathrm{org}} / \mathrm{N}$ ratio (fully aquatic-deep water conditions), relatively depleted $\delta^{13} \mathrm{C}$ values (more $\mathrm{C}_{3}$ but less $\mathrm{C}_{4}$ land plants) and vice versa. The prominent palaeomonsoon events documented in this study are: (i) $11,100-10,700$ cal yr BP with a weak ISM, (ii) 10,700 to 8600 cal $\mathrm{yr}$ BP characterized by intensified ISM, corresponding to the Early Holocene Optimum, (iii) 8600 to 4500 cal yr BP with a weakened ISM (iv) 4500 to 3300 cal yr BP characterized by fluctuating monsoonal conditions, (v) 3300 cal yr BP to the Present with a slight increasing trend in ISM. A similar pattern is also documented in many palaeomonsoon records from the region, which indicate that Shantisagara sediments were able to record regional climatic variations as well. 
Keywords: Magnetic susceptibility; pedogenesis; palaeorainfall; lake sediments; Holocene; southern India.

\section{Introduction}

The Indian summer monsoon (ISM; also known as the southwest monsoon) is a vital component of the Asian monsoon system and is the main source of freshwater for people of the Indian sub-continent. During the past few decades, there have been large-scale variations in monsoonal precipitation, leading to excessive floods and severe droughts in different parts of India. This has been largely attributed to global warming (Church and White, 2006; Roxy et al., 2016). There is a need to study variations of ISM during the geologic past, as it will help in understanding the present changes and model future monsoonal variations. Palaeoarchives, such as marine (Thamban et al., 2007; Kessarkar et al., 2013; Naik et al., 2014; Saraswat et al., 2013, 2016) and lake (Prasad et al., 2014; Rawat et al., 2015a,b) sediments, speleothems (Yadava et al., 2004), and tree-rings (Borgaonkar et al., 2010) have been widely used to reconstruct the ISM variability with different temporal resolution. Although marine sediments provide a long record of palaeomonsoon, their temporal resolution is poor and major climatic events during the Holocene are not well documented except for a few studies (Nigam et al., 1995; Staubwasser et al., 2003). In this regard, lake sediments have the potential of providing high-resolution records of palaeomonsoon. Compared to marine sediments, lake sediments provide direct evidence of the past events on a local or regional scale, with a relatively high temporal resolution. There have been studies on many lake and palaeolake deposits from western India (Prasad et al., 2014), northwestern India (Dixit et al., 2014a,b) and the Himalaya (Rawat et al., 2015a,b; Mishra et al., 2015) to reconstruct the ISM variability. However, very few lakes from southern India have been investigated for the reconstruction of Holocene ISM variability (Shankar et al., 2006; Warrier and Shankar, 2009; Warrier et al., 2014; Sandeep et al., 2015; Bhattacharyya et al., 2015) 
most of them provide monsoonal history of only the Late Holocene. Hence, it needs to be verified whether major monsoonal events, reported by many researchers, like the strengthening of ISM during the Early Holocene (Prasad et al., 2014), its weakening after 7 ka BP (Fleitmann et al., 2007; Demske et al., 2009), dry episodes or abrupt weakening of ISM around $8.2 \mathrm{ka} \mathrm{BP}$ and 4.2 ka BP (Staubwasser et al., 2003; Dixit et al., 2014a, b) were widespread phenomena and prevalent in southern India too.

In this study, we have adopted a multi-proxy approach (environmental magnetism, sedimentology, organic geochemistry and carbon isotopes) on the sediments deposited in Shantisagara (hereafter referred to as SS), a large lake located in southern India, to reconstruct the ISM variability during the Holocene.

Environmental magnetism is the systematic study of magnetic properties of soil and sediment samples. Magnetic minerals are ubiquitous and their presence in sediments and soils provides a sensitive medium to record changes in environmental conditions (Evans and Heller, 2003). These minerals may be produced, transported and deposited in different depositional basins. By studying the magnetic mineral concentration, grain-size and mineralogy, it is possible to identify the environmental processes operating in the catchment area. Secondary magnetic minerals also form from iron leached out from parent rocks by chemical processes or biogenic effects (Dearing et al., 1996) near the soil surface during weathering and pedogenesis (Dearing et al., 1997). The secondary magnetic minerals, eroded from the catchment and deposited on lake beds, form the basis of palaeoclimatic reconstruction. The technique has several advantages over others in being easy, rapid, sensitive, and non-destructive.

Down-core variations of particle size in sediments indicate changes in transport energy, lake level and provenance (Conroy et al., 2008). Rainfall plays a crucial role in the transport and deposition of these sediments from the catchment to the lake basin. During 
periods of high rainfall, the velocity of the transporting medium increases, enhancing the influx of coarse sediments in the lake. During periods of low rainfall, however, fine sediments are carried to deep water regions of the lake, due to the reduction in stream velocity (Chen et al., 2004; Conroy et al., 2008). Hence, sediments containing coarse (fine) particles indicate high (low) rainfall conditions.

Organic matter in sediments originates from the complex mixture of lipids, carbohydrates, proteins, and other biochemicals produced by organisms that live both in the lake and its watershed (Meyers and Ishiwatari, 1993; Meyers and Lallier-Verges, 1999). It provides information about lacustrine palaeoenvironments as the type and abundance of plant life in and around the lake change, as do the composition and amount of the resulting organic matter. The advantage of lacustrine organic proxies is that short-term processes that affect organic matter delivery and burial are amplified in the sediment record because of the high sedimentation rate and high primary productivity in lakes (Meyers, 2003). The $\mathrm{C}_{\text {org }} / \mathrm{N}$ ratio of organic matter may be used to differentiate between organic matter derived from aquatic algae/plankton and that derived from terrestrial plants. The $\mathrm{C}_{\text {org }} / \mathrm{N}$ ratio together with the isotopic signature of organic matter help to differentiate between contributions from $\mathrm{C}_{3}$ and $\mathrm{C}_{4}$ terrestrial plants, which in turn, may be used to infer the climatic conditions of the period during which they lived.

\section{Regional setting}

\subsection{Location, physiography and geology}

Shantisagara Lake (Fig. 1) is situated in Channagiri Taluk of Davanagere District, Karnataka State in southern India $\left(14^{\circ} 8^{\prime} 34^{\prime \prime N}\right.$; $\left.75^{\circ} 52^{\prime} 56^{\prime \prime E}\right)$. It is a large lake, covering an area of $\sim 25 \mathrm{sq} . \mathrm{km}$. The average water depth is $5 \mathrm{~m}$. The lake is in its natural setting and receives sediments from the catchment during the SW monsoon. It is not connected to any river network and there are no major industries in the vicinity of the lake. Although human 
settlements are present near the lake, there are no major pollution or garbage sources and the lake water is clean. Small round boats are used for fishing in the lake. But there are no mechanized boats. Therefore, it is reasonable to assume that the magnetic (and other) properties of Shantisagara (SS) sediments must be a reflection of natural processes only and may be correlatable with the climate of the lake catchment. The western and southern sides of the lake have undulating hills (Fig. 1). They are covered by the Sulekere State Forest. The maximum elevation of the area is about $800 \mathrm{~m}$. The northern and eastern sides are nearly plain and have a relatively low elevation (around $620 \mathrm{~m}$ ) where small scale agriculture is carried. The geology of the area is confined to the Chitradurga Group of the Dharwar Super Group and the Peninsular gneissic complex. The main rock types are migmatites and granodioritic to tonalitic gneisses belonging to the Peninsular Gneissic Group. Also present are quartz-chlorite schist with orthoquartzite, acid volcanics, greywacke-argillite and basal polymict conglomerate - all belonging to the Chitradurga Group (Geological and Mineral Map of Karnataka and Goa, 1981; Radhakrishna and Vaidyanadhan, 1994). The Lake and the surrounding area are a part of the Shimoga Basin. The soil is mostly reddish brown, clayey loam. Sandy loam is also present in some areas (Karnataka Forest Department, 2003).

\subsection{Climate and vegetation}

About $80 \%$ of the annual rainfall is received during the southwest monsoon from June to September. The rainfall data (1900-2010 A.D.) for Channagiri Station (India Meteorological Department; IMD) indicates that the annual rainfall varies from 419 to 1400 $\mathrm{mm}$ with an average of $795 \mathrm{~mm}$. (There are about 50 rainy days in a year (Karnataka Forest Department, 2003). The mean daily maximum temperature is $35.8^{\circ} \mathrm{C}$ and the mean minimum daily temperature $22.2{ }^{\circ} \mathrm{C}$. There is a rapid increase in temperature after January and the hottest month is April. Humidity is high during rainy season and exceeds $60 \%$. The driest period of the year is from January to March when the relative humidity is $<35 \%$ during 
daytime. Winds are generally light with some increase in speed during the monsoons (Karnataka Forest Department, 2003). Sulekere and the Bhadrapur State Forests, which belong to the Shantisagara Range, Bhadravati Forest Division, are located in the eastern side of the lake. The vegetation of the area falls under the categories of tropical dry teak-bearing forest and dry deciduous scrubs (Karnataka Forest Department, 2003).

\section{Materials and methods}

\subsection{Materials}

A 1.3-m sediment core (SS-1) from Shantisagara was collected in November 2007 by pushing a PVC pipe (diameter: 1.5 inch; water depth $=5 \mathrm{~m}$ ) into the sediment column. In order to obtain high-resolution data, the core was sub-sampled at intervals of $0.5 \mathrm{~cm}$. The sub-samples were stored in plastic bags. Environmental magnetic analysis was carried out for all the sub-samples $(n=264)$, whereas organic geochemical $(n=20)$, carbon isotopic $(n=$ 20), particle size $(n=23)$ and ${ }^{14} \mathrm{C}$ studies $(n=3)$ were carried out on selected sub-samples. Samples of surface $(n=10)$ and sub-surface $(n=23)$ soils from the lake catchment were also collected (Fig. 1b). The details of samples and sampling methods are provided by Sandeep et al. (2012).

\subsection{Methodology}

\subsubsection{AMS ${ }^{14} \mathrm{C}$ dating}

Carbon-14 dating by accelerator mass spectrometry was carried out on the organic matter of bulk sediment samples from selected depths (Table 1) at the Xi'an Accelerator Mass Spectrometer Center, Institute of Earth Environment, CAS, China. The ${ }^{14} \mathrm{C}$ ages were calibrated using the code clam (Version 2.2; Blaauw, 2010) which runs on the open source software 'R' (Version 3.3.2; R Development Core Team, 2013) and uses IntCal13.14C radiocarbon calibration data (Reimer et al., 2013). An age-depth model (Fig. 2) was constructed by linear interpolation model. Sedimentation rate was calculated from the age- 
depth model. The R code of clam calculates the confidence intervals for undated levels from the calibrated age distribution (at $95 \%$ interval) of every dated depth and the age-model is drawn through these models and the calibrated age calculated (Blaauw, 2010) for every depth.

\subsubsection{Environmental magnetic measurements}

Environmental magnetic properties of sediment samples were measured using standard rock magnetic methods (Walden et al., 1999). Low- $\left(0.47 \mathrm{kHz} ; \chi_{\mathrm{lf}}\right)$ and high- (4.7 $\left.\mathrm{kHz} ; \chi_{\mathrm{hf}}\right)$ frequency magnetic susceptibility were measured on a Bartington Susceptibility Meter (Model MS2B) with a dual-frequency sensor. $\mathrm{A} \mathrm{Fe}_{3} \mathrm{O}_{4}(1 \%)$ standard was used to calibrate the sensor. Using the $\chi_{\mathrm{lf}}$ and $\chi_{\mathrm{hf}}$ values, the percentage frequency-dependent susceptibility $\left(\chi_{\mathrm{fd}} \%\right)$ was calculated by using the formula, $\chi_{\mathrm{fd}} \%=\left(\left(\chi_{\mathrm{lf}}-\chi_{\mathrm{hf}}\right) / \chi_{\mathrm{lf}}\right) \times 100$ (Dearing, 1999a). Anhysteretic remanent magnetisation (ARM) was induced in the samples using a Molspin AF demagnetiser (with an ARM attachment) set with a peak alternating field of 100 milli Tesla (mT) and a DC biasing field of $0.04 \mathrm{mT}$. The ARM induced was measured on a Molspin spinner fluxgate magnetometer. The susceptibility of ARM ( $\left.\chi_{\text {ARM }}\right)$ was calculated by dividing the mass-specific ARM by the size of the biasing field $(0.04 \mathrm{mT}=$ 31.84 Am-1; Walden, 1999). Isothermal remanent magnetisation (IRM) was induced in the samples at increasing field strengths $(20,60,100,300,500$ and $1000 \mathrm{mT})$ using a Molspin pulse magnetiser and the remanence acquired measured using the Molspin spinner fluxgate magnetometer. The isothermal remanence induced at $1 \mathrm{~T}$ field (the maximum field attainable in the Environmental Magnetism Laboratory, Mangalore University) was considered as the saturation isothermal remanent magnetisation (SIRM). The sediment samples were ovendried at $35{ }^{\circ} \mathrm{C}$ and the dry sample weight was used to calculate the magnetic parameter values on a mass-specific basis. To determine the magnetic grain size and mineralogy of magnetic

minerals, inter-parametric ratios like $\chi_{\mathrm{ARM}} / \mathrm{SIRM}, \chi_{\mathrm{ARM}} / \chi_{\mathrm{lf}}, \chi_{\mathrm{ARM}} / \chi_{\mathrm{fd}}, \mathrm{SIRM} / \chi_{\mathrm{lf}}$, and S-ratio, 
and HIRM were calculated (Maher et al., 1999; Walden, 1999; Evans and Heller, 2003). The S-ratio used in this study involved not the classical IRM-300mT (Thompson and Oldfield, 1986) but the forward field IRM $_{300 \mathrm{mT}}$ (Bloemendal et al., 1992; Heslop, 2009). Similarly, forward field IRM I00mT $_{3}$ was used for calculating HIRM (Maher et al., 1999).

\subsubsection{Particle Size Analysis}

Particle size analysis was carried out on 23 sub-samples. About $4 \mathrm{~g}$ of each sediment sample was used for the analysis. The organic matter and carbonate contents were removed by treating the samples with $30 \% \mathrm{H}_{2} \mathrm{O}_{2}$ and $10 \%$ acetic acid respectively. The sand fraction was separated by wet-sieving through an ASTM test sieve no. 230 (62 $\mu \mathrm{m}$ pore diameter). After removal of sand, the silt + clay fraction was transferred to a $1000 \mathrm{ml}$ measuring cylinder. $1 \mathrm{~g}$ of sodium hexametaphosphate was added to prevent flocculation. After making it up to $1000 \mathrm{ml}$ volume, the silt and clay fractions were determined using pipette analysis (Carver, 1971). The column containing silt and clay was stirred vigorously for about one minute using a long stirring rod. After 20 seconds of stoppage of stirring, $20 \mathrm{ml}$ of the liquid was pipetted out from $20 \mathrm{~cm}$ depth that contains the silt + clay fraction. After 3 hours 10 minutes, $20 \mathrm{ml}$ of the liquid was pipetted out from $5 \mathrm{~cm}$ depth that contains only the clay fraction. The total weight of the clay fraction was calculated by multiplying the weight of clay by 50. A value of $1 \mathrm{~g}$ was subtracted from the value obtained to account for the weight of sodium hexametaphosophate. Similarly, the total weight of the silt + clay fraction was also calculated. From these values, the total weight of the silt fraction was determined. The three fractions (sand, silt and clay) are expressed as percentages.

\subsubsection{Organic Geochemistry}

Organic geochemistry $\left(\mathrm{C}, \mathrm{N}, \mathrm{CaCO}_{3}\right.$ and $\left.\delta^{13} \mathrm{C}\right)$ was determined for 20 samples. Bulk sediment samples were dried in a hot air oven at $40{ }^{\circ} \mathrm{C}$ and finely ground and homogenized 
using an agate mortar and pestle. About $2 \mathrm{~g}$ of the sediment sample was taken in a beaker and $1 \mathrm{~N}$ dilute $\mathrm{HCl}$ added in small increments until effervescence stopped (Schumacher, 2002). It was kept overnight at room temperature to facilitate complete removal of carbonates. The sample was washed 3-4 times with deionised water and dried in the hot air oven at $100{ }^{\circ} \mathrm{C}$. Weight loss after the $\mathrm{HCl}$ treatment gives the weight of $\mathrm{CaCO}_{3}$ or inorganic carbon and is expressed as percentage (error $=<0.5 \%$ ). The organic carbon and nitrogen in the decarbonated samples were determined using a CHNS analyzer (Model: Elementar Vario EL III; error $=<0.1 \%$ ) at the Sophisticated Test and Instrumentation Centre, Cochin University of Science and Technology, Kochi. From the carbon and nitrogen percentages, $\mathrm{C}_{\mathrm{org}} / \mathrm{N}$ ratio was calculated and expressed as atomic ratio, which is obtained by multiplying the mass ratio with 1.167 (Meyers and Terranes, 2001).

\subsubsection{Carbon isotopic analysis}

To determine the $\delta^{13} \mathrm{C}$ of organic carbon, a small quantity $(\sim 1 \mathrm{~g})$ of sediment sample was treated with $10 \% \mathrm{HCl}$ for several hours, dried and heated at $900{ }^{\circ} \mathrm{C}$ along with $\mathrm{CuO}$ powder and silver foil (Northfelt et al., 1981). The $\mathrm{CO}_{2}$ evolved was purified cryogenically before injecting it into the mass spectrometer. The isotopic composition is expressed as $\delta^{13} \mathrm{C}$ in parts per thousand (\%) relative to the Vienna-Pee Dee Belemnite (V-PDB) standard. $(\delta=$ $\left(\left(R_{\text {sam }}\right)-\left(R_{\text {std }}\right)-1\right) \times 1000$ where $R_{\text {sam }}$ and $R_{\text {std }}$ refer to the ${ }^{13} \mathrm{C} /{ }^{12} \mathrm{C}$ ratio in the sample and the standard respectively). The external precession for the laboratory standard was $\pm 0.12 \%$ for $\delta^{13} \mathrm{C}$ (Yadava and Ramesh, 1999). For reproducibility check, a few replicates were run and they revealed no significant differences. The conversion of organic carbon to $\mathrm{CO}_{2}$ gas and the subsequent $\delta^{13} \mathrm{C}$ analysis using an isotope ratio mass spectrometer (Model: PDZ Europa GEO20-20) were carried out at the Physical Research Laboratory, Ahmedabad.

\section{Results}

\subsection{Chronology}


The chronology of the sediment core is constrained by three AMS ${ }^{14} \mathrm{C}$ dates. The calibrated age ranges at $95 \%$ confidence interval $(2 \sigma)$ and their weighted means are given in Table 1. The limited number of C-14 dates on the core and the uncertainties in chronology due to reservoir effect are lacunas in our study. Sedimentation rate varies from $0.04 \mathrm{~cm} / \mathrm{year}$ to $0.006 \mathrm{~cm} /$ year (Fig. 2). The average sedimentation rate is $0.019 \mathrm{~cm} / \mathrm{year}$, so that the $1.32 \mathrm{~m}$ core represents the past $\sim 11,100$ cal yr BP. Although the sediment core was sub-sampled at $0.5 \mathrm{~cm}$ interval, the record is yet not of high temporal resolution because of the low sedimentation rate. A possible reason for this is that being located in a low-rainfall area (average annual rainfall $=795 \mathrm{~mm}$; IMD), sediment delivery to SS may be low. Besides, the sediment delivered gets deposited over a large area $\left(\sim 25 \mathrm{~km}^{2}\right)$ of Shantisagara, resulting in a low sedimentation rate. Nevertheless, it covers the entire Holocene. Even with the low temporal resolution, therefore, it has the potential to reveal broad long-term trends in rainfall over the entire Holocene in southern India.

\subsection{Environmental magnetic properties of SS-1 sediments}

Environmental magnetic parameters showing the magnetic concentration, grain-size and mineralogy for core SS-1 are plotted against age in Fig. 3. Magnetic susceptibility $\left(\chi_{\mathrm{lf}}\right)$ indicates the total concentration of magnetic minerals present in a natural sample (Walden et al., 1999). The $\chi_{\text {lf }}$ values during the Holocene vary between $32.85 \times 10^{-8} \mathrm{~m}^{3} \mathrm{~kg}^{-1}(16 \mathrm{~cm} ; 1027$ cal yr BP) and $150.59 \times 10^{-8} \mathrm{~m}^{3} \mathrm{~kg}^{-1}(102.5 \mathrm{~cm} ; 10,439 \mathrm{cal} \mathrm{yr} \mathrm{BP})$ with an average of $114.81 \times$ $10^{-8} \mathrm{~m}^{3} \mathrm{~kg}^{-1}$. The high $\chi_{\mathrm{lf}}$ values throughout the core indicate that the magnetic signal recorded in SS-1 are primarily due to ferrimagnetic minerals, with little contribution from canted antiferromagnetic, paramagnetic and diamagnetic minerals (Thompson and Oldfield, 1986; Walden et al., 1999). Percent frequency-dependent susceptibility $\left(\chi_{\mathrm{fd}} \%\right)$ indicates the proportion of superparamagnetic (SP) grains (Dearing, 1999a). The formation of SP grains is mainly due to pedogenesis or fire activity (Evans and Heller, 2003; Oldfield and Crowther, 
2007). The $\chi_{\mathrm{fd}} \%$ values for the SS-1 sediments vary from $3.18 \%(16 \mathrm{~cm} ; 1027 \mathrm{cal} \mathrm{yr} \mathrm{BP})$ to $13.1 \%\left(26.5 \mathrm{~cm} ; 1738 \mathrm{cal}\right.$ yr BP; Fig. 3). The average $\chi_{\mathrm{fd}} \%$ value is $10.93 \%$. Such high values suggest that the samples have a high content of SP and fine grained magnetic minerals (Dearing, 1999a). The susceptibility of anhysteretic remanent magnetization $\left(\chi_{\mathrm{ARM}}\right)$ is biased towards magnetic minerals of stable single domain (SSD) grain size (Maher, 1988). Values of $\chi_{\text {ARM }}$ vary between $0.15 \times 10^{-5} \mathrm{~m}^{3} \mathrm{~kg}^{-1}(16 \mathrm{~cm} ; 1027 \mathrm{cal} \mathrm{yr} \mathrm{BP})$ and $1.46 \times 10^{-5} \mathrm{~m}^{3} \mathrm{~kg}^{-1}(102.5$ $\mathrm{cm} ; 10,439 \mathrm{cal} \mathrm{yr}$ BP) with an average of $1.01 \times 10^{-5} \mathrm{~m}^{3} \mathrm{~kg}^{-1}$. Saturation isothermal remanent magnetization (SIRM) is generally influenced by the concentration of all remanence-carrying magnetic minerals (Walden, 1999) and, hence, reflects the total magnetic mineral content (Oldfield, 1991). Values of SIRM range between $126.66 \times 10^{-5} \mathrm{Am}^{2} \mathrm{~kg}^{-1}(16 \mathrm{~cm} ; 1027 \mathrm{cal} \mathrm{yr}$ BP) and $911.97 \times 10^{-5} \mathrm{Am}^{2} \mathrm{~kg}^{-1}(92.5 \mathrm{~cm}$; $9994 \mathrm{cal} \mathrm{yr} \mathrm{BP})$ with an average of $622.6 \times 10^{-}$ ${ }^{5} \mathrm{Am}^{2} \mathrm{~kg}^{-1}$, suggesting a high concentration of magnetic minerals during the Holocene.

S-ratio $\left(\mathrm{IRM}_{300 \mathrm{mT}} / \mathrm{IRM}_{1000 \mathrm{mT}}\right)$ is indicative of the relative proportions of ferrimagnetic and antiferromagnetic minerals in the sample (Walden et al., 1999; Evans and Heller, 2003). A S-ratio value close to unity denotes the presence of magnetically "soft" minerals like magnetite and maghemite whereas significantly low values indicate the presence of magnetically "hard" minerals like hematite and goethite. Values of S-ratio in SS-1 are extremely high and fluctuate between 0.85 and 1.00 (Fig. 3), indicating the dominance of low-coercivity, magnetically "soft" minerals like magnetite and maghemite. This supports the fact that the magnetic mineralogy of SS-1 sediments is dominated by ferrimagnetic minerals like magnetite and maghemite. The presence of canted antiferromagnetic minerals like hematite in the samples is also evident from HIRM values (Fig. 3). The HIRM values fluctuate between a low of $0.10 \times 10^{-5} \mathrm{Am}^{2} \mathrm{~kg}^{-1}(44 \mathrm{~cm} ; 2924 \mathrm{cal} \mathrm{yr} \mathrm{BP})$ and a high of 134.87 $\times 10^{-5} \mathrm{Am}^{2} \mathrm{~kg}^{-1}(92.5 \mathrm{~cm}$; $9994 \mathrm{cal} \mathrm{yr} \mathrm{BP})$ with an average of $19.35 \times 10^{-5} \mathrm{Am}^{2} \mathrm{~kg}^{-1}$, suggesting the presence of high-coercivity magnetic minerals like hematite in SS-1. 
Inter-parametric ratios, $\chi_{\mathrm{ARM}} / \mathrm{SIRM}$ and $\chi_{\mathrm{ARM}} / \chi_{\mathrm{If}}$, are used to determine the magnetic grain size. High ratio values generally indicate a fine magnetic grain size and vice versa (Oldfield, 1991). Both the ratio values exhibit similar down-core variations as also evident from a statistically significant correlation between them $\left(r^{2}=0.57 ; \mathrm{n}=262 ; \mathrm{p}<0.0001\right)$. The $\chi_{\text {lf }} v s . \chi_{\mathrm{fd}} \%$ biplot (Fig. 4a) gives a fair indication of the presence of SP magnetic grains, which control the magnetic susceptibility signal in the sediment core. This is further corroborated by the $\chi_{\text {ARM }} v s . \chi_{\text {lf }}$ biplot (Fig. 4 b; also known as the King's Plot), which is used to estimate the concentration and grain size of magnetic minerals (King et al., 1982; Bloemendal et al., 2003). The SS-1 sediments have a high concentration of magnetic minerals and are predominantly fine-grained $(0.1-0.3 \mu \mathrm{m}$; Fig. $4 \mathrm{~b})$.

\subsection{Particle Size Analysis}

The three particle size classes (sand, silt and clay) in Shantisagara sediment samples exhibit considerable down-core variations (Fig. 3). The sand and clay contents range from 4 to $96.2 \%$ and from 2.4 to $90.8 \%$ respectively. The silt content is relatively low (0.3 to 11.2 $\%)$. The sand percentage exhibits a significant positive correlation of 0.68 with $\chi_{\mathrm{lf}}(\mathrm{n}=23 ; \mathrm{p}<$ $0.01)$ and 0.62 with $\chi_{\mathrm{fd}}(\mathrm{n}=23 ; \mathrm{p}<0.01)$. It also shows positive correlations with $\chi_{\mathrm{ARM}}(\mathrm{r}=$ $0.50 ; \mathrm{n}=23 ; \mathrm{p}<0.01)$ and SIRM $(\mathrm{r}=0.66 ; \mathrm{n}=23 ; \mathrm{p}<0.01)$. By contrast, clay percentage exhibits a negative correlation of -0.65 and -0.58 with $\chi_{\mathrm{lf}}$ and $\chi_{\mathrm{fd}}$ respectively $(\mathrm{n}=23 ; \mathrm{p}<$ $0.01)$. It is negatively correlated with $\chi_{\mathrm{ARM}}(\mathrm{r}=-0.46 ; \mathrm{n}=23 ; \mathrm{p}=0.03)$ and $\operatorname{SIRM}(\mathrm{r}=-0.63$; $\mathrm{n}=23 ; \mathrm{p}<0.01)$ as well. In fact, sand and clay abundances mirror each other in the sediment core $(r=-0.99, p=0.01 ; n=23)$. Silt content also exhibits a negative correlation with magnetic parameters. For e.g., -0.42 with $\chi_{\mathrm{lf}}(\mathrm{n}=23, \mathrm{p}=0.05)$ and -0.45 with $\chi_{\mathrm{fd}}(\mathrm{n}=23 ; \mathrm{p}=0.03)$. The changes in sand and clay abundances are probably related to rainfall variations. During periods of high (low) rainfall, a large (small) proportion of coarse sediments are transported to the centre of the lake due to the high (low) energy of the transporting medium (Chen et al., 
2004; Conroy et al., 2008). This is substantiated by the strong positive correlation of $\chi_{\text {lf }}$ with sand $\%$ and the negative correlation with clay $\%$. Hence, periods characterised by high $\chi_{\mathrm{lf}}$, high sand content and low clay percentage experienced high-rainfall conditions and vice versa (Fig. 3).

\subsection{Organic Geochemical, $\mathrm{CaCO}_{3}$ and Carbon Isotopic Analyses}

Figure 5 depicts the down-core variations of $\chi_{\mathrm{lf}}, \mathrm{CaCO}_{3}$, organic carbon, nitrogen, $\mathrm{C}_{\text {org }} / \mathrm{N}$ ratio and $\delta^{13} \mathrm{C}$. Carbonate content ranges from 0.01 to $4.2 \%$. Organic carbon content varies between 0.80 and $2.50 \%$ whereas nitrogen content ranges between 0.02 and $0.28 \%$. There is no systematic decrease of nitrogen content with age (Fig. 5). Also, there is a high positive correlation $\left(r^{2}=0.67 ; \mathrm{n}=20, \mathrm{p}<0.001\right)$ between the organic carbon and nitrogen contents (Fig. 6a), suggesting that they are organically bound and their losses are due to decomposition of the organic matter. Organic carbon content does not exhibit any significant positive correlation with $\chi_{\mathrm{lf}}$ whereas $\mathrm{N}$ content does $(\mathrm{r}=0.53 ; \mathrm{p}=0.01, \mathrm{n}=20)$. The atomic $\mathrm{C}_{\text {org }} / \mathrm{N}$ ratio values vary from 9.1 to 46.7 with an average of 19.6 and exhibit a high negative correlation with $\chi_{\mathrm{lf}}(\mathrm{r}=-0.72 ; \mathrm{p}<0.001 ; \mathrm{n}=20)$. The $\delta^{13} \mathrm{C}$ of organic matter varies from -24.8 to $-15.9 \%$ (Fig. 5$)$.

\section{Discussion}

\subsection{Origin of magnetic minerals in Shantisagara sediments}

Sediments contain magnetic minerals, which may be derived from different sources (Walden et al., 1999). Apart from detrital input, there may be contributions from bacterial magnetite (Snowball, 1994), authigenic greigite (Snowball, 1991) and anthropogenic magnetite derived from industrial activity, vehicular emissions, etc. (Gautam et al., 2004). Besides, there is also the possibility of diagenetic dissolution of magnetic minerals due to the decomposition of organic matter (Anderson and Rippey, 1988). Data for SS-1 sediment and 
catchment soil samples were plotted in the $\chi_{\mathrm{ARM}} / \chi_{\mathrm{If}} v s . \chi_{\mathrm{ARM}} / \chi_{\mathrm{fd}}$ diagram of Oldfield (2007) to examine if bacterial magnetite contributes to the magnetic signal (Fig. 7a). The sediment and soil samples plot in the envelope for soil, palaeosol and catchment-derived fine sediments. They exhibit considerably low ratio compared to the threshold values $\left(\chi_{\text {ARM }} / \chi_{\text {If }}<\right.$ 40 and $\chi_{\mathrm{ARM}} / \chi_{\mathrm{fd}}<1000$; Dearing, 1999b) reported for bacterial magnetite. Hence, the presence of bacterial magnetite in the samples is ruled out. The $\mathrm{SIRM} / \chi_{\mathrm{lf}}$ ratio for Shantisagara core sediment samples ranges from 3.9 to $6.8 \times 10^{3} \mathrm{~A} \mathrm{~m}^{-1}$ (Fig. 3), which is considerably below the threshold value for greigite $\left(40 \times 10^{3} \mathrm{~A} \mathrm{~m}^{-1}\right.$; Snowball, 1991). Hence, the presence of this iron sulphide mineral too may be ruled out. The down-core trends of inter-parametric ratios (indicative of magnetic grain size) $-\chi_{\mathrm{ARM}} / \chi_{\mathrm{lf}}, \chi_{\mathrm{ARM}} / \chi_{\mathrm{fd}}$ and $\chi_{\mathrm{ARM}} / \mathrm{SIRM}$ - (Fig. 3) do not exhibit any steep and simultaneous decrease. Therefore, it appears that magnetic dissolution has not affected the SS-1 magnetic record. The semi-quantitative magnetic granulometry plot of $\chi_{\mathrm{ARM}} / \mathrm{SIRM} v s . \chi_{\mathrm{fd}} \%$ (Dearing et al., 1997) was used to check the presence of anthropogenic/ lithogenic magnetic minerals (Fig. 7b). Most sediment samples plot in the SSD/SP transition range whereas surface and sub-surface soil samples do so in the coarse to fine SSD region. None of them plot in the MD+PSD grain size range, which is characteristic of magnetite that is anthropogenic (Gautam et al., 2004) or lithogenic (Maher and Thompson, 1992). The parameter $\chi_{\mathrm{fd}}$, which is proportional to the concentration of the superparamagnetic pedogenic component, exhibits a high correlation with $\chi_{\mathrm{lf}}(\mathrm{r}=0.95$, $\mathrm{p}<0.001, \mathrm{n}=262$ ), confirming the pedogenic origin of magnetite. The data presented above suggest that there are no contributions from bacterial/ anthropogenic magnetite and greigite to the SS-1 magnetic record nor is there any dissolution effect that could obliterate the magnetic record. Hence, it may be inferred that the magnetic signal is principally catchmentderived. The magnetically enhanced top-soil from the catchment is eroded, transported and deposited in SS. A magnetic grain size "sorting" is apparent from Fig. 7b. Catchment soils 
have a wide range of magnetic grain size (MD \& PSD to SSD/SP transition), but what is transported to SS is material of fine magnetic grain size (95\% of the samples in the SSD/SP transition range).

\subsection{The Magneto-climatic Record of Shantisagara Lake Sediments}

The down-core variations of environmental magnetic parameters of the Shantisagara sediment core are shown in Fig. 3. They exhibit considerable fluctuations during the past 11,100 years. The trends of parameters, $\chi_{\mathrm{lf}}, \chi_{\mathrm{fd}}, \chi_{\mathrm{ARM}}, \mathrm{SIRM}$, are nearly similar. High values for these parameters indicate high-rainfall conditions and vice versa. During the $\sim 11,100$ to 10,700 cal yr BP period, concentration-dependent parameters exhibit notably low values. However, the values are the highest during the $\sim 10,700$ to 8600 cal yr BP period. From 8600 to 4500 cal yr BP, the values are again low save for two peaks. Fluctuations in the values are documented between $\sim 4500$ and $3300 \mathrm{cal}$ yr BP. From $\sim 3300 \mathrm{cal} \mathrm{yr}$ BP to the present, the parameters do not exhibit much fluctuation but a slight increasing trend may be discerned.

The concentration-dependent parameters exhibit considerably high correlations with $\chi_{\mathrm{lf}}$ as evident by their similar trends (Fig. 3). The grain size-dependent parameters, $\chi_{\mathrm{ARM}} / \mathrm{SIRM}$ and $\chi_{\mathrm{ARM}} / \chi_{\mathrm{If}}$, do not exhibit any noteworthy long-term trends although short-term fluctuations are noted. Values of $\chi_{\mathrm{lf}}$ do not exhibit any significant correlation with these two ratios $\left(r=0.10\right.$ and 0.08 respectively). On a close scrutiny of the $\chi_{\mathrm{ARM}} / \mathrm{SIRM}$ trend, it is possible to note only subtle differences: Relatively high ratio values (= relatively fine magnetic grain size) correspond to relatively high $\chi_{\mathrm{lf}}$ values and vice versa. Hence, there is not much variation in magnetic grain size, suggesting that the climate of this region did not leave a strong imprint on magnetic grain size.

Magnetic mineralogy is mainly "soft" as indicated by the high S-ratio values (0.85 to 1.00). Although there are minor fluctuations, there is no long-term trend exhibited by S-ratio. 
Similarly, HIRM also exhibits short-term fluctuations. Besides, there are no specific periods characterized by increased contribution from magnetically "hard" minerals.

\subsection{Holocene record of palaeovegetation variations in the Shantisagara catchment}

High carbonate content is indicative of low rainfall or arid climatic conditions and vice versa (Chen et al., 2002; Warrier and Shankar, 2009). This appears to be the case in SS sediments as well: $\chi_{\mathrm{lf}}$ and carbonate content are negatively correlated $(\mathrm{r}=-0.72, \mathrm{p}<0.001$, $\mathrm{n}=20$ ). Low $\mathrm{C}_{\text {org }} / \mathrm{N}$ ratio values indicate deep water conditions in $\mathrm{SS}$ because of the predominance of aquatic plankton. Hence, a warm and wet climate may be inferred. A high $\mathrm{C}_{\text {org }} / \mathrm{N}$ ratio hints at a decreased contribution from plankton and shallow water conditions; hence, low rainfall may be discerned (Meyers and Lallier-Verges, 1999; Rühland et al., 2009). This is further exemplified by the fact that there is no significant correlation between $\mathrm{C}_{\text {org }} / \mathrm{N}$ and $\mathrm{C}_{\text {org }} \%$, indicating that the increase (decrease) in $\mathrm{C}_{\text {org }} / \mathrm{N}$ ratio is not due to high (low) terrigenous influx but due to a relative decrease (increase) in autochthonous contribution by plankton. Hence, there was an increased in wash of soil nutrients during highrainfall periods (Meyers and Lallier-Verges, 1999), resulting in increased aquatic productivity and low $\mathrm{C}_{\mathrm{org}} / \mathrm{N}$ ratio and vice versa. Stable carbon isotopic composition $\left(\delta^{13} \mathrm{C}\right)$ of organic matter in lakes depends on the dominance of its sources, either land derived or in-situ. It has characteristic values for the type of terrestrial vegetation: -22 to $-27 \%$ or $\mathrm{C}_{3}$ type pathway and -8 to $-13 \%$ for $\mathrm{C}_{4}$ type (Fig. 6a). Algae growing in freshwater lakes such as 'SS' use dissolved $\mathrm{CO}_{2}$ during photosynthesis, which is in isotopic equilibrium with atmospheric $\mathrm{CO}_{2}$. Therefore, $\delta^{13} \mathrm{C}$ values of algae may be indistinguishable from those of terrestrial organic matter from the catchment (Meyers, 2003). However, sources of organic matter in lake sediments may be better deciphered using the additional data of $\mathrm{C}_{\text {org }} / \mathrm{N}$ ratio in a $\mathrm{C}_{\text {org }} / \mathrm{N}$ ratio vs. $\delta^{13} \mathrm{C}$ plot (Fig. 6b). Based on the $\mathrm{C}_{\mathrm{org}} / \mathrm{N}$ ratio and carbon isotopic data of SS-1 sediments, two scenarios of climatic conditions may be inferred. 
Scenario 1: $C_{\text {org }} / N$ ratio $>20$ and $\delta^{13} C-18$ to $-15 \%$ :- High $\mathrm{C}_{\mathrm{org}} / \mathrm{N}$ ratio values may indicate a total absence of plankton due to shrinkage of lake area and low water level. Carbon isotopic values are close to those characteristic of $\mathrm{C} 4$ terrestrial plants. These features indicate arid climatic conditions.

Scenario 2: $C_{o r g} / N$ ratio $<20$ and $\delta^{13} C-25$ to $-16 \%$ :- Relatively high rainfall conditions and increased water levels are indicated by the presence of aquatics. More negative carbon isotopic values indicate a high proportion of $\mathrm{C} 3$ terrestrial plants and high rainfall conditions, whereas less negative or enriched $\delta^{13} \mathrm{C}$ values suggest a high proportion of $\mathrm{C} 4$ terrestrial plants and low-rainfall conditions. But overall, rainfall is high compared to Scenario 1.

5.4 The Palaeoclimate/Palaeoenvironment around Shantisagara Lake - A Summary based on multiple proxies

The palaeoclimate/ palaeoenvironment of the Shantisagara Lake area during the past 11,100 cal yr BP is reconstructed based on various proxies like environmental magnetism, sedimentology, organic geochemistry and carbon isotopes. The Holocene climate was earlier considered to be relatively stable (Lowe and Walker, 2014; Grootes et al., 1993; Dansgaard et al., 1993). However, later studies indicated variability in Holocene climate (Mayewski et al., 2004; Wanner et al., 2008, 2014). This is also reflected in the SS record with low- and highrainfall intervals. These intervals are delineated based mainly on magnetic parameters, but well supported by other proxies. The major climatic periods witnessed by the Shantisagara area are outlined below.

\section{I. $\sim 11,100$ to 10,700 cal yr BP}

The concentration-dependent parameters, $\chi_{\mathrm{If}}, \chi_{\mathrm{ARM}}$ and SIRM, exhibit low values during this period. Their average values are $103.3 \times 10^{-8} \mathrm{~m}^{3} \mathrm{~kg}^{-1}, 0.96 \times 10^{-5} \mathrm{~m}^{3} \mathrm{~kg}^{-1}$ and $614.9 \times 10^{-5} \mathrm{Am}^{2} \mathrm{~kg}^{-1}$ respectively. Prior to $11,000 \mathrm{cal} \mathrm{yr} \mathrm{BP}$, the values are remarkably low 
(average values being $89.1 \times 10^{-8} \mathrm{~m}^{3} \mathrm{~kg}^{-1}, 0.87 \times 10^{-5} \mathrm{~m}^{3} \mathrm{~kg}^{-1}$ and $548.3 \times 10^{-5} \mathrm{Am}^{2} \mathrm{~kg}^{-1}$ respectively). The lowest values are recorded at $\sim 10,700$ cal yr BP. Pedogenesis was weak during this period as indicated by the relatively low $\chi_{\mathrm{fd}}$ values $\left(8.1\right.$ to $13.1 \times 10^{-8} \mathrm{~m}^{3} \mathrm{~kg}^{-1}$; average $=11.1 \times 10^{-8} \mathrm{~m}^{3} \mathrm{~kg}^{-1}$ ) whose trend is similar to those of other concentrationdependent parameters. S-ratio also exhibits relatively low values, ranging from 0.9 to 0.99 . On the other hand, HIRM expectedly exhibits an opposite trend, with relatively high values (6.3 to $56.0 \times 10^{-5} \mathrm{Am}^{2} \mathrm{~kg}^{-1}$ ). After $10,700 \mathrm{cal} \mathrm{yr} \mathrm{BP}$, there is a rapid increase in the concentration-dependent parameters up to $10,700 \mathrm{cal}$ yr BP.

The carbonate $\%$ is relatively high during this period and varies from 0.34 to $4.22 \%$ $($ average $=1.97 \%)$. The $\mathrm{C}_{\mathrm{org}} / \mathrm{N}$ ratio varies from 10.8 to 46.7 (average $\left.=29.2\right)$. Two samples from this period exhibit high $\mathrm{C}_{\text {org }} / \mathrm{N}$ values of 44.8 and 46.7 , whereas one sample (with a slightly higher $\chi_{\text {lf }}$ ) has a low $\mathrm{C}_{\text {org }} / \mathrm{N}$ value. Such high $\mathrm{C}_{\text {org }} / \mathrm{N}$ ratio values indicate the complete absence of plankton, implying a low water level or even drying up of the lake. The $\mathrm{C}_{\text {org }}$ content ranges from 0.85 to $0.90 \%$ and $\mathrm{N}$ content from 0.02 to $0.09 \%$. The $\delta^{13} \mathrm{C}$ values range from -16.3 to $-23.2 \%$ (average $=-18.9 \%$ ). One sample with a slightly higher $\chi_{\text {lf }}$ exhibits a more depleted $\delta^{13} \mathrm{C}$ value of $-23.2 \%$. Except the time represented by this sample, the period is characterized by a high proportion of $\mathrm{C} 4$ plants (Scenario 1).

The various lines of evidence presented above suggest that rainfall was generally low during 11,100 to 10,700 cal yr BP before the advent of the Holocene. However, the monsoon had rapidly strengthened during the latter half of this period.

\section{II. $\sim 10,700$ to 8600 cal yr BP}

Magnetic parameters exhibit increased values during this period. In fact, they are the highest in the entire core. Values of $\chi_{\mathrm{lf}}$ range from 116.26 to $150.59 \times 10^{-8} \mathrm{~m}^{3} \mathrm{~kg}^{-1}$ (average $=$ $138.13 \times 10^{-8} \mathrm{~m}^{3} \mathrm{~kg}^{-1}$ ), those of $\chi_{\mathrm{ARM}}$ from 1.0 to $1.46 \times 10^{-5} \mathrm{~m}^{3} \mathrm{~kg}^{-1}$ (average $=1.3 \times 10^{-5} \mathrm{~m}^{3}$ 
$\mathrm{kg}^{-1}$ ), and SIRM from 628.0 to $912.0 \times 10^{-5} \mathrm{Am}^{2} \mathrm{~kg}^{-1}$ (average $=773.1 \times 10^{-5} \mathrm{Am}^{2} \mathrm{~kg}^{-1}$ ). There is also an increase in the concentration of SP grains (= higher pedogenesis) as evidenced by the high $\chi_{\mathrm{fd}}\left(\right.$ average $=15.8 \times 10^{-8} \mathrm{~m}^{3} \mathrm{~kg}^{-1}$ ) values. S-ratio exhibits slightly high and HIRM low values compared to the earlier period. A prominent peak in HIRM (a trough in S-ratio) values is documented at $~ 9997 \mathrm{cal} \mathrm{yr} \mathrm{BP.}$

The carbonate content is profoundly low with values ranging from 0.01 to $0.18 \%$. The average $\mathrm{C}_{\text {org }}$ and $\mathrm{N}$ contents are $1.26 \%$ and $0.13 \%$ respectively with sharp peaks around 9800 cal yr BP. The $\mathrm{C}_{\mathrm{org}} / \mathrm{N}$ ratio range from 10.1 to 15.8 , indicating an increased contribution from aquatic plants. There is a shift in the source of organic matter from essentially terrestrial (without any planktonic contribution) in the earlier period to a mixed (planktonic + terrestrial) vegetation during this period. Except one sample (which has a depleted $\delta^{13} \mathrm{C}$ value of $-24.8 \%$ ), the others exhibit much enriched values of -16.6 and $-17.9 \%$ (Scenario 2 ). The $\delta^{13} \mathrm{C}$ values of -16.6 and $-17.9 \%$ indicate an increased contribution from $\mathrm{C} 4$ land plants. $\mathrm{A}$ value of $-24.8 \%$, on the other hand, indicates a higher contribution from C3 land plants, indicating a higher rainfall.

The data presented above suggest that this period is characterized by relatively high rainfall compared to the Present; in fact, it is the highest for the entire Holocene. Thus, it may represent the Early Holocene Optimum (Ciais et al., 1992; Bookhagen et al., 2006).

\section{8600 to 4500 cal yr BP}

This period is characterized by notably low values for the parameters, $\chi_{\mathrm{If}}, \chi_{\mathrm{ARM}}$ and SIRM except for two prominent peaks. The values of $\chi_{\text {If }}$ range from 88 to $128 \times 10^{-8} \mathrm{~m}^{3} \mathrm{~kg}^{-1}$ (average $=103.4 \times 10^{-8} \mathrm{~m}^{3} \mathrm{~kg}^{-1}$ ), those of $\chi_{\mathrm{ARM}}$ from 0.7 to $1.2 \times 10^{-5} \mathrm{~m}^{3} \mathrm{~kg}^{-1}$ (average $=0.93 \times$ $10^{-5} \mathrm{~m}^{3} \mathrm{~kg}^{-1}$ ) and SIRM from 476.5 to $739.0 \times 10^{-5} \mathrm{Am}^{2} \mathrm{~kg}^{-1}$ (average $=559.7 \times 10^{-5} \mathrm{Am}^{2} \mathrm{~kg}^{-1}$ ).

The carbonate content ranges from 0.09 to $1.6 \%$. The average $\mathrm{C}_{\text {org }}$ content is $1.02 \%$ and the average $\mathrm{N}$ content $0.07 \%$. The $\mathrm{C}_{\text {org }} / \mathrm{N}$ ratio varies from 10.1 to 23.9 (average $=17.8$ ), 
which indicates a mixed (both planktonic and terrestrial) origin of organic matter. But around 5600 and $7800 \mathrm{cal} \mathrm{yr} \mathrm{BP,} \mathrm{the} \mathrm{C}_{\text {org }} / \mathrm{N}$ ratio exhibits values greater than 20 (23.9 and 22.3) even though the values are not as high as for the Early Holocene, suggesting a significant reduction in plankton. Carbon isotopic values range from -15.9 to $-18.9 \%$, indicating an increased contribution from C4 plants (Scenario 1). Hence, the lake had not dried up fully even under arid conditions as evidenced by the average $\mathrm{C}_{\mathrm{org}} / \mathrm{N}$ value of 17.8 .

On the basis of the data discussed above, this period appears to be characterized by low rainfall/ arid climatic conditions. It may correspond to the period of Mid-Holocene aridity documented in some palaeomonsoonal records (Bryson and Swain, 1981; Sukumar et al., 1993).

\section{4500 to 3300 cal yr BP}

The concentration-dependent parameters exhibit rapid fluctuations during this period. The $\chi_{\mathrm{lf}}$ values range from $65.5-137.3 \times 10^{-8} \mathrm{~m}^{3} \mathrm{~kg}^{-1}, \chi_{\mathrm{ARM}}$ values from 0.5 to $1.1 \times 10^{-5} \mathrm{~m}^{3} \mathrm{~kg}^{-1}$ and SIRM values from 332.8 to $846.9 \times 10^{-5} \mathrm{Am}^{2} \mathrm{~kg}^{-1}$. A major peak in these parameters is discernible at $\sim 4300$ cal $\mathrm{yr} \mathrm{BP}$ after which there is a rapid decline, with the lowest value recorded at $\sim 3600 \mathrm{cal} \mathrm{yr} \mathrm{BP}$. Thereafter, the parameters again register a rapid increase up to 3300 cal yr BP. The $\chi_{\mathrm{fd}}$ values also exhibit a similar trend of rapid fluctuations.

The $\mathrm{C}_{\text {org }} / \mathrm{N}$ ratio registers an increase in the value from 9.1 to 36.3 , suggesting a steady change from plankton-dominated deep water conditions to fully terrestrial (total absence of aquatics) vegetation. The $\mathrm{C}_{\mathrm{org}} / \mathrm{N}$ ratio is probably indicative of drying up of the lake. But the carbonate content (1.5 to $1.8 \%$ ) and $\delta^{13} \mathrm{C}$ values (-16.6 to $-17.7 \%$ ) vary only a little. A value of $-17.7 \%$ is due to higher contributions from $\mathrm{C} 4$ plants (because the $\mathrm{C}_{\text {org }} / \mathrm{N}$ ratio is significantly high; fully terrestrial and total absence of aquatics). The $\mathrm{C}_{\text {org }}$ content does not exhibit any rapid fluctuations whereas $\mathrm{N}$ content exhibits a decrease (0.13-0.05\%). 
Considering the foregoing data, this period appears to be a short interval of fluctuating monsoonal conditions. The monsoon intensity was strong in the beginning of this period, but subsequently waned to its minimum and increased thereafter.

\section{3300 cal yr BP to the Present}

After $~ 3300$ cal yr BP, $\chi_{\text {lf }}, \chi_{\text {ARM }}$, SIRM values are constant.. The values are high but not as high as those recorded during the Early Holocene. The average $\chi_{\mathrm{lf}}, \chi_{\mathrm{ARM}}, \mathrm{SIRM}$ values are $114.8 \times 10^{-8} \mathrm{~m}^{3} \mathrm{~kg}^{-1}, 0.97 \times 10^{-5} \mathrm{~m}^{3} \mathrm{~kg}^{-1}$ and $586.9 \times 10^{-5} \mathrm{Am}^{2} \mathrm{~kg}^{-1}$ respectively. The lowest values (not only for this but the entire period represented by the core) are documented at $\sim 1028$ cal yr BP $\left(\chi_{\mathrm{lf}}=32.8 \times 10^{-8} \mathrm{~m}^{3} \mathrm{~kg}^{-1} ; \chi_{\mathrm{ARM}}=0.15 \times 10^{-5} \mathrm{~m}^{3} \mathrm{~kg}^{-1}\right.$ and $\operatorname{SIRM}=126.6 \times$ $10^{-5} \mathrm{Am}^{2} \mathrm{~kg}^{-1}$ respectively). The $\chi_{\mathrm{fd}}$ values also exhibit a similar trend.

Excluding one sample with a markedly high $\mathrm{C}_{\text {org }} / \mathrm{N}$ ratio value, the average values are relatively low (9.9-18.7; average $=13.3$; Scenario 2$)$, indicating a mixed vegetation. The anomalous sample also has an enriched $\delta^{13} \mathrm{C}$ value $\left(-17.5 \%\right.$ ). The $\delta^{13} \mathrm{C}$ values display a decreasing trend towards the Present $(-18$ to $-20.9 \%$; average $=-18.9 \%$ ) which points to an increasing contribution from C3 land plants.

The data presented above indicate that the monsoon has been steady from $3300 \mathrm{cal} \mathrm{yr}$ BP to the Present.

\subsection{Comparison with other Palaeoclimatic Records from the Region}

Figure 8 illustrates the correspondence between the magnetic susceptibility data of SS-1 and palaeoclimatic records from different proxies. The weak monsoonal conditions documented in the SS-1 record prior to $\sim 10,700$ cal yr BP, i.e., before the dawn of the Holocene (the Younger Dryas) is also reported by several investigators (Tiwari et al., 2006; Altabet et al., 2002 and references therein). Staubwasser et al. (2003) documented a reduced discharge from the Sindhu (Indus) River during the Younger Dryas. 
Strong monsoonal conditions are indicated by the SS-1 record during $\sim 10,700-8,600$ cal yr BP, coinciding with the increased insolation then $\left(14^{\circ} \mathrm{N}\right.$ latitude, June 21 ; Laskar, 1990). Thamban et al. (2007) also reported peak monsoonal conditions between 9500 and 8000 cal yr BP based on proxies like magnetic susceptibility and elemental concentrations of a sediment core collected from the western continental margin of India. A maximum in the Sindhu River discharge off the Pakistan coast and thermocline anoxia were established in the Arabian Sea during this period (Staubwasser et al. 2002, 2003). Based on the denitrification intensity (which is closely related to the SW monsoon wind strength) recorded in sediment cores from the Oman margin, Altabet et al. (2002) documented an increased productivity during this period. This Early Holocene precipitation maximum is also recorded in the speleothem records from northern Oman (Neff et al., 2001) and marine sediments off Oman (Gupta et al., 2003). Thamban et al.'s (2007) study also revealed intensification of monsoon during the Early Holocene that occurred in two abrupt steps at 9400 and 9100 years B.P, with the main event between 9100 and 8500 years BP. The SS-1 record also shows that the monsoon intensified abruptly but the intensification started slightly earlier at $\sim 10,760 \mathrm{cal} \mathrm{yr}$ BP. But this Early Holocene high rainfall interval ended synchronously according to both the records; besides, the ending was gradual and not abrupt like the intensification event. A sudden decrease in the Sindhu discharge at 8400 cal yr BP in the NE Arabian Sea was also documented (Staubwasser et al., 2002). The trend towards aridity began around the same time as per the SS-1 record as well. The Early Holocene monsoon intensification is also evident in recent records from lacustrine (Sarkar et al., 2015; Rawat et al., 2015a,b) and marine (Kessarkar et al., 2013; Saraswat et al., 2016) sediments.

Fleitmann et al. (2003) and Gupta et al. (2003, 2005) documented a declining trend in the Indian monsoon precipitation up to $1.5 \mathrm{ka}$ after the maximum at $\sim 8.5 \mathrm{ka}$. They also proposed that the monsoon trend broadly followed the insolation curve at $65^{\circ} \mathrm{N}$. Sarkar et al. 
(2000), based on oxygen and carbon isotopic analyses of planktonic foraminifera, inferred that the monsoon decreased steadily from $10 \mathrm{ka}$ to $\sim 2 \mathrm{ka}$. But such a continuous decreasing trend is not documented in the SS-1 as well as other palaeoclimatic records from the region although the Early Holocene high precipitation event is discernible in all of them. In fact, the SS-1 record shows fluctuating monsoonal conditions during the Holocene with abrupt intervals of strong and weak monsoon. On the contrary, Bhushan et al. (2001) and Agnihotri et al. (2003), based on palaeoproductivity proxies $\left(\mathrm{CaCO}_{3}\right.$ and $\left.\mathrm{C}_{\text {org }}\right)$ and denitrification intensity documented respectively in sediment cores from the eastern Arabian Sea, reported increasing SW monsoon intensity from $\sim 10$ to $2 \mathrm{ka}$.

The $\sim 8600$ to 4500 cal yr BP period is characterized by a particularly weak monsoon in the SS-1 record. Insolation also exhibited a decreasing trend during this period. Archaeological and other continental records from the Indian sub-continent depict a substantial weakening of the summer monsoon around 7000 cal yr BP (Gupta et al. 2006). However, a small peak in monsoon is shown by the SS-1 record during this time and a low rainfall recorded slightly earlier ( 7800 cal. yr. BP). But except for two smaller peaks, rainfall was profoundly low during this period as per the SS-1 record. Thamban et al. (2007) documented a significantly weak monsoon between 6000 and 5500 cal yr BP. A decreased productivity was documented in the Oman margin (Gupta et al., 2005) during the same period. Saraswat et al. (2016) documented a distinct shift in evaporation-precipitation at 6400 cal yr BP accompanied by a cooling in the SST, which was evident in the low primary productivity in the eastern Arabian Sea. This event is not only recorded in marine sediments but also in the lacustrine sediments of Central India (Lonar Lake; Sarkar et al. 2015) and the Himalaya (Rawat et al., 2015 a, b). It is noteworthy that insolation reached minimal values around this time, after which it was steady albeit with a gentle increasing trend.

\section{Conclusions}


The present study of environmental magnetism, sedimentology, organic geochemistry and carbon isotopes besides geochronology of SS-1 core sediments from Shantisagara Lake provides palaeomonsoonal/ palaeovegetational record of southern India for the Holocene Period. The following conclusions may be drawn from the present study:

- The 11,100-year palaeoclimatic record provided by SS-1 core of Shantisagara is the longest reported from any lake in Peninsular India.

- Periods of high rainfall are characterised by high values of concentration-dependent magnetic parameters like $\chi_{\mathrm{lf}}, \chi_{\mathrm{fd}}, \chi_{\mathrm{ARM}}$ and SIRM, high sand content, low $\mathrm{C}_{\mathrm{org}} / \mathrm{N}$ ratio (fully aquatic-deep water conditions), more depleted $\delta^{13} \mathrm{C}$ values (more $\mathrm{C} 3$ terrestrial plants). Periods of low rainfall, on the contrary, are typified by low values of concentration-dependent magnetic parameters $\left(\chi_{\mathrm{lf}}, \chi_{\mathrm{fd}}, \chi_{\mathrm{ARM}}\right.$ and SIRM), high clay content, high $\mathrm{C}_{\text {org }} / \mathrm{N}$ ratio (total absence of aquatics; dried up lake), and less negative $\delta^{13} \mathrm{C}$ values (more $\mathrm{C} 4$ terrestrial plants).

- The Indian summer monsoon (ISM) was significantly weak over southern India before the advent of the Holocene Period, i.e., 11,100-10,700 cal yr BP. This period may represent the end stage of the Younger Dryas cold event.

- The Early Holocene Period (10,700 to 8600 cal yr BP) was characterized by intensified ISM. During this period isolation was also the highest, which might have led to intensification of monsoon.

- The ISM weakened during the 8600-4500 cal yr BP period (Mid-Holocene). This period corresponds to the Mid-Holocene aridity event documented in some palaeomonsoonal records; the sudden weakening of ISM around 8200 cal yr BP corresponds to the $8.2 \mathrm{ka}$ cold event. Insolation exhibits a decreasing trend during this period. 
- $\quad$ The 4500 to 3300 cal yr BP period witnessed fluctuating monsoonal conditions. From $4500 \mathrm{cal}$ yr BP onwards the monsoon began to weaken, corresponding to the $4.2 \mathrm{ka}$ cold aridity event. After waning to its minimum, ISM regained the earlier intensity.

- The monsoon has been steady from 3300 cal yr BP to the Present.

- There are similarities between many palaeomonsoonal records from the region and the SS-1 record, which indicate that Shantisagara sediments were able to record not only the local, but regional climatic variations as well.

\section{Acknowledgements}

The magnetic instruments used in this study were procured from grants made available by the erstwhile Department of Ocean Development (now Ministry of Earth Sciences), Government of India, through a research project (DOD/11-MRDF/1/48/P/94ODII/12-10-96) to RS. SK thanks UGC (University Grants Commission), New Delhi, for financial assistance in the form of Junior and Senior Research Fellowships. AKW thanks the Council of Scientific and Industrial Research (CSIR), Government of India, for a senior research fellowship. We thank the Editor and the Reviewers for their valuable comments, which helped in improving the manuscript.

\section{References}

Agnihotri, R., Bhattacharya, S.K., Sarin, M.M., Somayajulu, B.L.K., 2003. Changes in the surface productivity and subsurface denitrification during the Holocene: a multi proxy study from the eastern Arabian Sea. The Holocene 13, 701-713.

Altabet, M.A., Higginson, M.J., Murray, D.W. 2002. The effect of millennial changes in Arabian Sea dentitrification on atmospheric $\mathrm{CO}_{2}$. Nature 415, 159-162.

Anderson, N.J., Rippey, B., 1988. Diagenesis of magnetic minerals in the recent sediments of a eutrophic lake. Limnol. Oceanogr. 33, 1476-1492.

Bhattacharyya, A., Sandeep, K., Misra, S., Shankar, R., Warrier, A.K., Weijian, Z., Zuefeng, L., 2015. Vegetational and Climatic Variations during the past 3100 years in Southern India: Evidence from Pollen, Magnetic Susceptibility and Particle Size Data. Environ. Earth Sci. 74, 3559-3572.

Bhushan, R., Dutta, K., Somayajulu, B.L.K., 2001. Concentrations and burial fluxes of organic and inorganic carbon on the eastern margins of the Arabian Sea. Mar. Geol. 178, 95-113. 
Blaauw, M., 2010. Methods and code for 'classical' age-modelling of radiocarbon sequences. Quat. Geochronol. 5, 512-518.

Bloemendal, J., King, J. W., Hall, F. R. and Doh, S.-J. 1992. Rock magnetism of Late Neogene and Pleistocene deep-sea sediments: Relationship to sediment source, diagenetic processes, and sediment lithology. J. Geophys. Res., 97(B4), 4361-4375.

Bloemendal, J., Ehrmann, W., Hambrey, M.J., McKelvey, B.C., Matthews, R., Whitehead, J.M., 2003. Geochemical and rock magnetic records from sediments of the Cenozoic Pagodroma Group, Prince Charles Mountains, East Antarctica: implications for provenance and weathering. Antarct. Sci. 15 (3), 365-378.

Bookhagen, B., Fleitmann, D., Nishiizumi, K., Strecker, M.R., Thiede, R.C., 2006. Holocene monsoonal dynamics and fluvial terrace formation in the northwest Himalaya, India. Geology 34 (7), 601-604.

Borgaonkar, H.P., Sikder, A.B., Ram, S., Pant, G.B., 2010. El Niño and related monsoon drought signals in 523-year-long ring width records of teak (Tectona grandis L.F.) trees from south India. Palaeogeogr. Palaeoclimatol. Palaeoecol. 285, 74-84.

Bryson, R.A., Swain, A.M., 1981. Holocene variations in monsoon rainfall in Rajasthan. Quat. Res. 16, 135-145.

Carver, R.E., 1971. Procedures in sedimentary petrology. Wiley-Interscience, John Wiley and Sons Inc., $653 \mathrm{p}$.

Chen, J., Wan, G., Wang, F., Zhang, D.D., Huang, R., Zhang, F., Schmidt, R., 2002. Environmental records of carbon in recent lake sediments. Sci. China. Ser. D 45 (10), 875-884.

Chen, J., Wan, G., Zhang, D.D., Zhang, F., Huang, R., 2004. Environmental records of lacustrine sediments in different time scales: Sediment grain size as an example. Sci. China. Ser. D 47 (10), 954-960.

Church, J., White, N., 2006. A $20^{\text {th }}$ century acceleration in global sea-level rise. Geophys. Res. Lett. 33, L01602. doi:10.1029/2005GL024826.

Ciais, P., Petit, J.R., Jouzel, J., Lorius, C., Barkov, NI., Lipenkov, V., Nicolaiev, V., 1992. Evidence for an early Holocene climatic optimum in the Antarctic deep ice-core record. Clim. Dynam. 6, 169-177.

Conroy, J.L., Overpeck, J.T., Cole, J.E., Shanahan, T.M., Steinitz-Kannan 2008. Holocene changes in eastern tropical Pacific climate inferred from a Galápagos lake sediment record. Quat. Sci. Rev. 27, 1166-1180.

Dansgaard, W., Johnsen, S.J., Clausen, H.B., Dahljensen, D., Gundestrup, N.S., Hammer, C.U., Hvidberg, C.S., Steffensen, J.P., Sveinbjörnsdóttir, A.E., Jouzel, J., Bond, G. 1993. Evidence for general instability of past climate from a 250-kyr ice-core record. Nature 364(6434), 218-220.

Dearing, J.A., Hay, K.L., Baban, S.M.J., Huddleston, A.S., Wellington, E.M.H., Loveland, P.J., 1996. Magnetic susceptibility of soil: an evaluation of conflicting theories using a national data set. Geophys. J. Int. 127, 728-734.

Dearing, J.A., Bird, P.M., Dann, R.J.L., Benjamin, S.F., 1997. Secondary ferromagnetic minerals in Welsh soils: a comparison of mineral magnetic detection methods and implications for mineral formation. Geophys. J. Int. 130, 727-736. 
Dearing, J. A., 1999a. Magnetic susceptibility, in: Walden, J., Smith, J.P., Oldfield, F. (Eds.), Environmental Magnetism - A practical guide. Technical Guide No. 6, Quaternary Research Association, London, pp. 35-62,

Dearing, J.A., 1999b. Holocene environmental change from magnetic proxies in lake sediments, in: Maher, B.A., Thompson, R., (Eds.), Quaternary Climates, Environments and Magnetism. Cambridge University Press, Cambridge, pp. 231-278.

Demske, D., Tarasov, P.E.,Wünnemann, B., Riedel, F., 2009. Late glacial and Holocene vegetation, Indian monsoon and westerly circulation dynamics in the Trans-Himalaya recorded in the pollen profile from high-altitude Tso Kar Lake, Ladakh, NW India. Palaeogeogr. Palaeoclimatol. Palaeoecol. 279 (3), 172-185.

Dixit, Y., Hodell, D.A., Sinha, R., Petrie, C.A., 2014a. Abrupt weakening of the Indian summer monsoon at $8.2 \mathrm{kyr}$ BP Earth Planet. Sci. Lett. 391, 16-23.

Dixit, Y., Hodell, D.A., Petrie, C.A., 2014b. Abrupt weakening of the summer monsoon in northwest India 4100 yr ago. Geology 42 (4), 339-342.

Dykoski, C.A., Edwards, R.L., Cheng, H., Yuan, D., Cai, Y., Zhang, M., Lin, Y., Qing, J., An, Z., Revenaugh, J., 2005. A high-resolution absolute-dated Holocene and deglacial Asian monsoon record from Dongge Cave, China. Earth Planet. Sci. Lett. 233, 71-86.

Evans, M.E., Heller, F., 2003. Environmental magnetism. Principles and applications of enviromagnetics. San Diego, USA: Academic Press, 299 p.

Fleitmann, D., Burns, S.J., Mudelsee, M., Neff, U., Kramers, J., Mangini, A. and Matter, A. (2003). Holocene forcing of the Indian monsoon recorded in a stalagmite from Southern Oman. Science, v. 300, pp. 1737-1739.

Fleitmann, D., Burns, S.J., Mangini, A., Mudelseed, M., Kramers, J., Villa, I., Neffe, U., AlSubbary, A.A., Buettner, A., Hippler, D., Matter, A., 2007. Holocene ITCZ and Indian monsoon dynamics recorded in stalagmites from Oman and Yemen (Socotra). Quat. Sci. Rev. 26, 170-188.

Gautam, P., Blaha, U., Appel, E., Neupane, G., 2004. Environmental magnetic approach towards the quantification of pollution in Kathmandu urban area, Nepal. Phys. Chem. Earth 29, 973-984.

Geological and Mineral Map of Karnataka and Goa, 1981. Compiled by: Swaminath, J., Ramiengar, A.S., Ziauddin, M., Narayanamurthy, J., Seshadri, T.S., Ramakrishnan, M., Viswanatha, M.N. and Murthy, T.S.S. Geological Survey of India, scale 1: 500,000, 1 sheet.

Grootes, P. M., Stuvier, M., White, J. W. C., Johnsen, S. J., Jouzel, J., 1993. Comparison of oxygen isotope records from GISP2 and GRIP Greenland ice cores. Nature 366, 552554.

Gupta, A.K., Anderson, D.M., Overpeck, J.T., 2003. Abrupt changes in the Asian southwest monsoon during the Holocene and their links to the North Atlantic Ocean, Nature 421, 354-357.

Gupta, A.K., Anderson, D.M., Pandey, D.N., Singhvi, A.K., 2006. Adaptation and human migration, and evidence of agriculture coincident with changes in the Indian summer monsoon the Holocene. Curr. Sci. 90, 1082-1090.

Gupta, A.K., Das, M., Anderson, D.M., 2005. Solar influence on the Indian summer monsoon during the Holocene. Geophys. Res. Lett. 32, doi:10.1029/2005GL022685. 
Heslop, D. 2009. On the statistical analysis of the rock magnetic S-ratio. Geophys. Jour. Int., $178,159-161$.

India Meteorological Department, 2008. Rainfall data for Chennagiri Station. Government of India, New Delhi.

Karnataka Forest Department, 2003. Working plan for the forests of Bhadravathi division. Aranya Bhavan, Bangalore, Government of Karnataka.

Kessarkar, K.M., Rao, V.P., Naqvi, S.W.A., Karapurkar, S.G. 2013. Variation in the Indian Summer Monsoon intensity during the Bølling-Ållerød and Holocene. Paleoceanography 28(3), 413-425.

King, J.W., Banerjee, S.K., Marvin, J., Õzdemir, Õ., 1982. A comparison of different magnetic methods for determining the relative grain size of magnetite in natural materials: Some results from lake sediments. Earth Planet. Sci. Lett. 59, 404-419.

Lamb, A.L., Wilson, G.P., Leng, M.J., 2006. A review of coastal palaeoclimate and relative sea-level reconstructions using $\delta^{13} \mathrm{C}$ and $\mathrm{C} / \mathrm{N}$ ratios in organic material. Earth Sci. Rev. 75 (1-4), 29-57.

Laskar, J., 1990. The chaotic motion of the solar system: A numerical estimate of the size of the chaotic zones. Icarus 88, 266-291.

Lowe, J.J., Walker, M.J.C., 2014. Reconstructing Quaternary Environments. Third Edition.

Routledge, London.

Maher, B.A., Taylor, R.M., 1988. Formation of ultrafine-grained magnetite in soils. Nature 336, 368-370.

Maher, B.A., Thompson, R., 1992. Paleoclimatic significance of the mineral magnetic record of the Chinese loess and paleosols. Quat. Res. 39, 155-170.

Maher, B.A., Thompson, R., Hounslow, M.W., 1999. Quaternary Climates, Environments and Magnetism. Cambridge University Press, Cambridge.

Maher, B.A., 1988. Magnetic properties of some synthetic sub-micron magnetites. Geophys. J. 94, 83-96.

Meyers, P.A., Ishiwatari, R., 1993. Lacustrine organic geochemistry - an overview of indicators of organic matter sources and diagenesis in lake sediments. Org. Geochem. 20, 867-900.

Meyers, P.A., Lallier-Verges, E., 1999. Lacustrine sedimentary organic matter records of Late Quaternary paleoclimates. J. Paleolimnol. 21, 345-372.

Meyers, P.A., Terranes, J.L., 2001. Sediment organic matter, in: Last, W.M., Smol, J.P., (Eds.), Tracking Environmental Change Using Lake Sediments. Volume 2: Physical and Geochemical Methods. Kluwer Academic Publishers, Dordrecht, Netherlands.

Meyers, P.A., 2003. Applications of organic geochemistry to paleolimnological reconstructions: a summary of examples from the Laurentian Great Lakes. Org. Geochem. 34, 261-289.

Mishra, P.K., Prasad, S., Anoop, A., Plessen, B., Jehangir, A., Gaye, B., Menzel, P., Weise, S.M., Yousuf, A.R., 2015. Carbonate isotopes from high altitude Tso Moriri Lake (NW Himalayas) provide clues to late glacial and Holocene moisture source and atmospheric circulation changes. Palaeogeogr. Palaeoclimatol. Palaeoecol. 425, 76-83. 
Naik, S.S., Godad, S.P., Naidu, P.D., Tiwari, M., Paropkari, A.L., 2014. Early- to lateHolocene contrast in productivity, OMZ intensity and calcite dissolution in the eastern Arabian Sea. The Holocene, 24, 749-755.

Neff, U., Burns, S.J., Mudelsee, M., Mangini, A., Matter, A., 2001. Strong coherence between solar variability and the monsoon in Oman between 9 and 6 kyrs ago. Nature 411, 290-293.

Nigam, R., Khare, N., Nair, R.R. 1995. Foraminiferal evidences for 77 years cycle of drought in India and its possible modulation by the Gleissberg solar cycle. J Coast Res 11, 10991107.

Northfelt, D.W., DeNiro, M.J., Epstein, S., 1981. Hydrogen and carbon isotopic ratios of the cellulose nitrate and saponifiable lipid fractions prepared from annual growth rings of a California redwood. Geochim. Cosmochim. Acta 45, 1895-1898.

Oldfield, F., 1991. Environmental Magnetism - A personal perspective. Quat. Sci. Rev. 10, 73-85.

Oldfield, F., 1994. Toward the discrimination of fine grained ferrimagnets by magnetic measurements in lake and near-shore marine sediments. J. Geophys. Res. 99, 9045-9050.

Oldfield, F., 2007. Sources of fine grained magnetic minerals in sediments: a problem revisited. The Holocene 17 (8), 1265-1271.

Oldfield, F., Crowther, J., 2007. Establishing fire incidence in temperate soils using magnetic measurements. Palaeogeogr. Palaeoclimatol. Palaeoecol. 249, 362-369.

Prasad, S., Anoop, A., Riedel, N., Sarkar, S., Menzel, P., Basavaiah, N., Krishnan, R., Fuller, D., Plessen, B., Gaye, B., Röhl, U., Wilkes, H., Sachse, D., Sawant, R., Wiesner, M.G., Stebich, M., 2014. Prolonged monsoon droughts and links to Indo-Pacific warm pool: a Holocene record from Lonar Lake, central India. Earth Planet. Sci. Lett. 391, 171-182.

R Development Core Team, 2013. R: A language and environment for statistical computing. $\mathrm{R}$ Foundation for Statistical Computing, Vienna, Austria. ISBN 3-900051-07-0, http://www.r-project.org

Radhakrishna, BP, Vaidyanadhan, R.V. 1994. Geology of Karnataka. Geological Society of India, Bangalore.

Rawat, S., Gupta, A.K., Srivastava, P., Sangode, S.J., Nainwal, H.C., 2015a. A 13,000 year record of environmental magnetic variations in the lake and peat deposits from the Chandra valley, Lahaul: implications to Holocene monsoonal variability in the NW Himalaya. Palaeogeogr. Palaeoclimatol. Palaeoecol. 440, 116-127.

Rawat, S., Gupta, A.K., Sangode, S.J., Srivastava, P., Nainwal, H.C., 2015b. Late Pleistocene-Holocene vegetation and Indian summer monsoon record from the Lahaul, Northwest Himalaya, India. Quat. Sci. Rev. 114, 167-181.

Reimer, P.J., Bard, E., Bayliss, A., Beck, J.W., Blackwell, P.G., Bronk Ramsey, C., Buck, C.E., Edwards, R.L., Friedrich, M., Grootes, P.M., Guilderson, T.P., Haflidason, H., Hajdas, I., Hatté, C., Heaton, T.J., Hoffmann, D.L., Hogg, A.G., Hughen, K.A., Kaiser, K.F., Kromer, B., Manning, S.W., Niu, M., Reimer, R.W., Richards, D.A., Scott, E.M., Southon, J.R., Turney, C.S.M., van der Plicht, J., 2013. IntCal13 and Marine13 radiocarbon age calibration curves, 0-50,000 years cal BP. Radiocarbon 55, 1869-1887.

Roxy, M. K., Modi, A., Murutugudde, R., Valsala, V., Panickal, S., Prasanna Kumar, S., Ravichandran, M.., Vichi, M., Levy, M. 2016. A reduction in marine primary 
productivity driven by rapid warming over the tropical Indian Ocean. Geophys. Res. Lett., 43, 826-833

Rühland, K., Jacques, J.M., Beierle, B.D., Lamoureux, S.F., Dyke, A.S., John, P., 2009. Lateglacial and Holocene paleoenvironmental changes recorded in lake sediments, Brock Plateau (Melville Hills), Northwest Territories, Canada. The Holocene 19 (7), 1005-1016.

Sandeep, K., Shankar, R., Warrier, A.K., Weijian, Z., Xuefeng, L., 2015. The environmental magnetic record of palaeoenvironmental variations during the past 3100 years: A possible solar influence? J. Appl. Geophys. 118, 24-36.

Sandeep, K., Warrier, A.K., Harshavardhana, B.G., Shankar, R., 2012. Rock magnetic investigations of surface and sub-surface soil samples from five lake catchments in tropical Southern India. Int. J. Environ. Res. 6 (1), 1-18.

Saraswat, R., Naik, D.K., Nigam, R., Gaur, A.S. 2016. Timing, cause and consequences of mid-Holocene climate transition in the Arabian Sea, Quat. Res. 86(2), 162-169.

Saraswat, R., Lea, D.W., Nigam, R., Mackensen, A., Naik, D.K., 2013. Deglaciation in the tropical Indian Ocean driven by interplay between the regional monsoon and global teleconnections. Earth Planet. Sci. Lett. 375, 166-175.

Sarkar, A., Ramesh, R., Somayajulu, B.L.K., Agnihotri, R., Jull A.J.T., Burr, G.S., 2000. High resolution Holocene monsoon record from the eastern Arabian Sea. Earth Planet. Sci. Lett. 177, 209-218.

Sarkar, S., Prasad, S., Wilkes, H., Riedel, N., Stebich, M., Basavaiah, N., Sachse, D. 2015. Monsoon source shifts during the drying mid-Holocene: Biomarker isotope based evidence from the core 'monsoon zone' (CMZ) of India. Quat. Sci. Rev., 123, 144-157.

Schumacher, B. A., 2002. Methods for the Determination of Total Organic Carbon (TOC) in Soils and Sediments. Ecological Risk Assessment Support Center, Office of Research and Development, US. Environmental Protection Agency, 23 p.

Shankar, R., Prabhu, C.N., Warrier, A.K., Vijayakumar, G.T., Sekar, B., 2006. A multidecadal rock magnetic record of monsoonal variations during the past 3,700 years from a tropical Indian tank. J. Geol. Soc. India, 68 (3), 447-459.

Snowball, I., 1991. Magnetic hysteresis properties of greigite $\left(\mathrm{Fe}_{3} \mathrm{~S}_{4}\right)$ and a new occurrence in Holocene sediments from Swedish Lappland. Phys. Earth Planet. Inter. 68, 32-40.

Snowball, I., 1994. Bacterial magnetite and the magnetic properties of sediments in a Swedish lake. Earth Planet. Sci. Lett. 126, 129-142.

Staubwasser, M., Sirocko, F., Grootes P.M., Erlenkeuser, H., 2002. South Asian monsoon climate change and radiocarbon in the Arabian Sea during early and mid Holocene. Paleoceanography, 17, 1063. doi:10.1029/2000PA000608.

Staubwasser, M., Sirocko, F., Grootes P.M., Segl, M., 2003. Climate change at the 4.2 ka BP termination of the Indus valley civilization and Holocene south Asian monsoon variability. Geophys. Res. Lett. 30, 1425. doi:10.1029/2002GL016822.

Sukumar, R., Ramesh, R., Pant, R.K., Rajagopalan, G., 1993. A $\delta^{13}$ C record of late Quaternary climate change from tropical peats in southern India. Nature 364, 703-706.

Thamban, M., Kawahata, H., Rao, V.P., 2007. Indian Summer Monsoon Variability during the Holocene as Recorded in Sediments of the Arabian Sea: Timing and Implications. J. Oceanogr. 63, 1009-1020. 
Thompson, R., Oldfield, F., 1986. Environmental Magnetism. Allen \& Unwin, London, $227 \mathrm{p}$.

Tiwari, M., Ramesh, R., Somayajulu, B.L.K., Jull, A.J.T., Burr, G.S., 2006. Paleomonsoon precipitation deduced from a sediment core from the equatorial Indian Ocean. Geo Mar. Lett. 26, 23-30.

Walden, J.F., Oldfield, F., Smith, J., 1999. Environmental Magnetism: A Practical Guide, No.6. Quaternary Research Association, London, 243 p.

Walden, J., 1999. Remanence measurements, in: Walden, J., Smith, J.P., Oldfield, F., (Eds.), Environmental Magnetism - A practical guide, Technical Guide No. 6, Quaternary Research Association, London. pp. 63-88.

Wanner, H., Beer, J., Bütikofer, J., Crowley, T.J., Cubasch, U., Fluckiger, J., Goosse, H., Grosjean, M., Joos, F., Kaplan, J.O., Ku“ttel, M., Mu“ller, S.A., Prentice, I.C., Solomina, O., Stocker, T.F., Tarasov, P., Wagner, M., Widmann, M., 2008. Mid- to Late Holocene climate change: an overview. Quat. Sci. Rev. 27, 1791-1828.

Wanner, H., Mercolli, L., Grosjean, M., Ritz, S. P., 2014. Holocene climate variability and change; a data-based review. J. Geol. Soc. 172, 254-263.

Warrier, A.K., Shankar, R., 2009. Geochemical evidence for the use of magnetic susceptibility as a paleorainfall proxy in the tropics. Chem. Geol. 265, 553-562.

Warrier, A.K., Shankar, R., Sandeep, K., 2014. Sedimentological and carbonate data evidence for lake level variations during the past 3700 years from a southern Indian lake. Palaeogeogr. Palaeoclimatol. Palaeoecol. 397, 52-60.

Yadava, M.G., Ramesh, R., 1999. Speleothems - useful proxies for past monsoon rainfall. J. Sci. Ind. Res. 58, 339-348.

Yadava, M.G., Ramesh, R., Pant, G.B., 2004. Past monsoon rainfall variations in peninsular India recorded in a 331-year-old speleothem. The Holocene 14 (4), 517-524. 


\section{FIGURE CAPTIONS}

Fig. 1. (a) Topographic map of Shantisagara Lake and surrounding areas (Source: Survey of India Toposheet Number $48 \mathrm{~N} / 16$ ). Contours are in meters. Inset map shows the location of the lake in southern India. SS-1 is the core location; (b) Satellite image of Shantisagara Lake and surrounding areas along with the core location (Source: Google Earth) (SS1 = core location; S1-S10 = location of surface soil samples from the lake catchment; P1 = location of sub-surface soil samples); (c) Digital Elevation Model (DEM) of Shantisagara Lake (blue outline) and surrounding areas. Undulating hills are present to the west and south of the lake.

Fig. 2. Age-depth model for the Shantisagara sediment core (SS-1). It was constructed with the linear interpolation model using the weighted mean of probability distribution of calibrated ${ }^{14} \mathrm{C}$ ages by ' $\mathrm{R}$ ' code of clam (Version 2.2; Blaauw, 2010). The sedimentation rate is given for each interval. The $2 \sigma$ probability range of calibrated dates is shown in black and that of interpolated ages in grey. The black line is the best age-depth model drawn through the weighted means of all the calendar ages.

Fig. 3. Down-core variations of rock magnetic and particle size data for Shantisagara sediment core (SS-1). The entire record may be broadly divided into five zones or periods based on multi-proxy data.

Fig. 4. (a) Biplot of $\chi_{\mathrm{lf}} v s$. $\chi_{\mathrm{fd}} \%$ for SS-1 sediment samples. Note that $\chi_{\mathrm{fd}} \%$ values $>10$ indicate fine-grained magnetic minerals and with a high proportion of SP magnetic grains; (b) Biplot of $\chi_{\text {If }} v s . \chi_{\text {ARM }}$ (King et al., 1982) for SS-1 sediments. The data show fine-grained magnetic minerals in the size range of $0.1-0.3 \mu \mathrm{m}$.

Fig. 5. Down-core variations of magnetic susceptibility $\left(\chi_{\mathrm{lf}}\right)$, carbonate $\%$, organic carbon $\left(\mathrm{C}_{\mathrm{org}}\right)$, nitrogen, $\mathrm{C} / \mathrm{N}$ ratio and $\delta^{13} \mathrm{C}$ for selected samples of Shantisagara sediments. 
Note: $\mathrm{C}_{\mathrm{org}}$ does not exhibit any significant relationship with $\chi_{\mathrm{lf}}$, whereas $\mathrm{N}$ content exhibits a positive correlation. Carbonate and $\mathrm{C} / \mathrm{N}$ ratio exhibit a high negative correlation with $\chi_{\mathrm{lf}}$. Although $\delta^{13} \mathrm{C}$ also exhibits a negative correlation, it is not statistically significant $(\mathrm{r}=-0.36)$. The five climatic phases are shown using broken lines. The two scenarios based on $\mathrm{C} / \mathrm{N}$ ratio and $\delta^{13} \mathrm{C}$ values are also displayed (for details see text).

Fig. 6. (a) C vs. $\mathrm{N}$ biplot for SS-1 sediment samples. The high correlation between the two parameters indicates that they are organically bound; (b) $\mathrm{C} / \mathrm{N}$ ratio and organic $\delta^{13} \mathrm{C}$ values for bacteria, marine and freshwater planktonic algae and $\mathrm{C}_{3}$ and $\mathrm{C}_{4}$ terrestrial plants (after Lamb et al., 2006). Data for Shantisagara Lake sediment samples are shown. The two scenarios described in the text are shown using different symbols. $=$ Scenario 1: $\mathrm{C} / \mathrm{N}$ ratio $>20$ and $\delta^{13} \mathrm{C}-18$ to $-15 \% \quad \boldsymbol{\Delta}=$ Scenario $2: \mathrm{C} / \mathrm{N}$ ratio $<20$ and $\delta^{13} \mathrm{C}-25$ to $-16 \%$ )

Fig. 7. (a) Bi-logarithmic plot of $\chi_{\mathrm{ARM}} / \chi_{\mathrm{lf}}$ versus $\chi_{\mathrm{ARM}} / \chi_{\mathrm{fd}}$ (Oldfield, 1994, 2007) for Shantisagara sediments and catchment soils (Sandeep et al., 2012). Note that samples with bacterial magnetite plot near the top right corner with high values for both the ratios (> 40 and > 1000 respectively). Shantisagara sediments and catchment soils plot in a separate envelope with considerably lower values for the two ratios, confirming the absence of bacterial magnetite; (b) Semi-quantitative magnetic granulometry biplot of $\chi_{\mathrm{ARM}} / \mathrm{SIRM}$ vs. $\chi_{\mathrm{fd}} \%$ (after Dearing et al., 1997 and Maher and Taylor, 1988), with data for the five zones of Shantisagara Lake sediments and catchment soils. Note that most of the sediment samples plot in the SSD/SP transition range, indicating the absence of MD+PSD grains that are suggestive of 
anthropogenic/lithogenic origin. Catchment soil samples exhibit a coarser grain size (coarse to fine SSD) compared to sediment samples.

Fig. 8. Comparison of (a) Shantisagara $\chi_{\mathrm{lf}}$ record with: (b) insolation data $\left(14^{\circ} \mathrm{N}\right.$, June 21 ; Laskar, 1990); (c) Magnetic susceptibility (k) of core SK 148/55 collected from the western continental margin of India (Thamban et al. 2007); (d) $\delta^{18} \mathrm{O}$ of $G$. ruber from sediments off the Sindhu (Indus) River mouth (Staubwasser et al., 2003); (e) $\delta^{18} \mathrm{O}$ of stalagmite (Q5) from Oman (Fleitmann et al., 2003); (f) $\delta^{13} C_{w a x}$ record from Lonar Lake sediments (Sarkar et al., 2015); (g) $\delta^{18} \mathrm{O}$ record from marine sediments (Saraswat et al., 2016); (h) $\delta^{18} \mathrm{O}$ record of a stalagmite from Dongge Cave, China (Dykoski et al., 2005); and (i) $\delta^{15} \mathrm{~N}$ record from a sediment core off Oman (Altabet et al., 2002). 
Table 1

\begin{tabular}{|c|c|c|c|c|c|c|}
\hline $\begin{array}{c}\text { Sample } \\
\text { No. }\end{array}$ & $\begin{array}{c}\text { Xi'an Lab } \\
\text { ID }\end{array}$ & $\begin{array}{c}\text { Depth } \\
(\mathbf{c m})\end{array}$ & $\begin{array}{c}{ }^{\mathbf{1 4}} \mathbf{C} \text { age } \\
(\mathbf{y r} \text { BP) }\end{array}$ & $\begin{array}{c}\boldsymbol{\delta}^{\mathbf{1 3}} \mathbf{C} \\
\mathbf{( \% o})\end{array}$ & $\begin{array}{c}\text { Weighted mean } \\
\text { of calibrated } \\
\text { age (years) }\end{array}$ & $\begin{array}{c}\text { Calibrated age } \\
\mathbf{2 - \sigma} \\
(\mathbf{c a l y r} \text { BP })\end{array}$ \\
\hline SSA1 & XA3002 & $54-55$ & $3420 \pm 30$ & $-15.85 \pm 0.47$ & 3669 & $3818-3581$ \\
\hline SSA2 & XA3339 & $93-94$ & $9100 \pm 30$ & $-23.21 \pm 0.22$ & 10247 & $10369-10199$ \\
\hline SSA3 & XA3340 & $122-123$ & $9540 \pm 40$ & $-23.83 \pm 0.22$ & 10902 & $11081-10709$ \\
\hline
\end{tabular}

Note: The AMS ${ }^{14} \mathrm{C}$ dates were calibrated using the code clam (Version 2.2; Blaauw, 2010), which runs on the open source software ' $R$ ' (Version 3.3.2; R Development Core Team, 2013) and uses the IntCal13.14C radiocarbon calibration data (Reimer et al., 2013). 


\section{TABLE CAPTION}

Table 1. AMS ${ }^{14} \mathrm{C}$ dates on bulk organic matter from the Shantisagara Lake sediment core SS-1. 
(a)

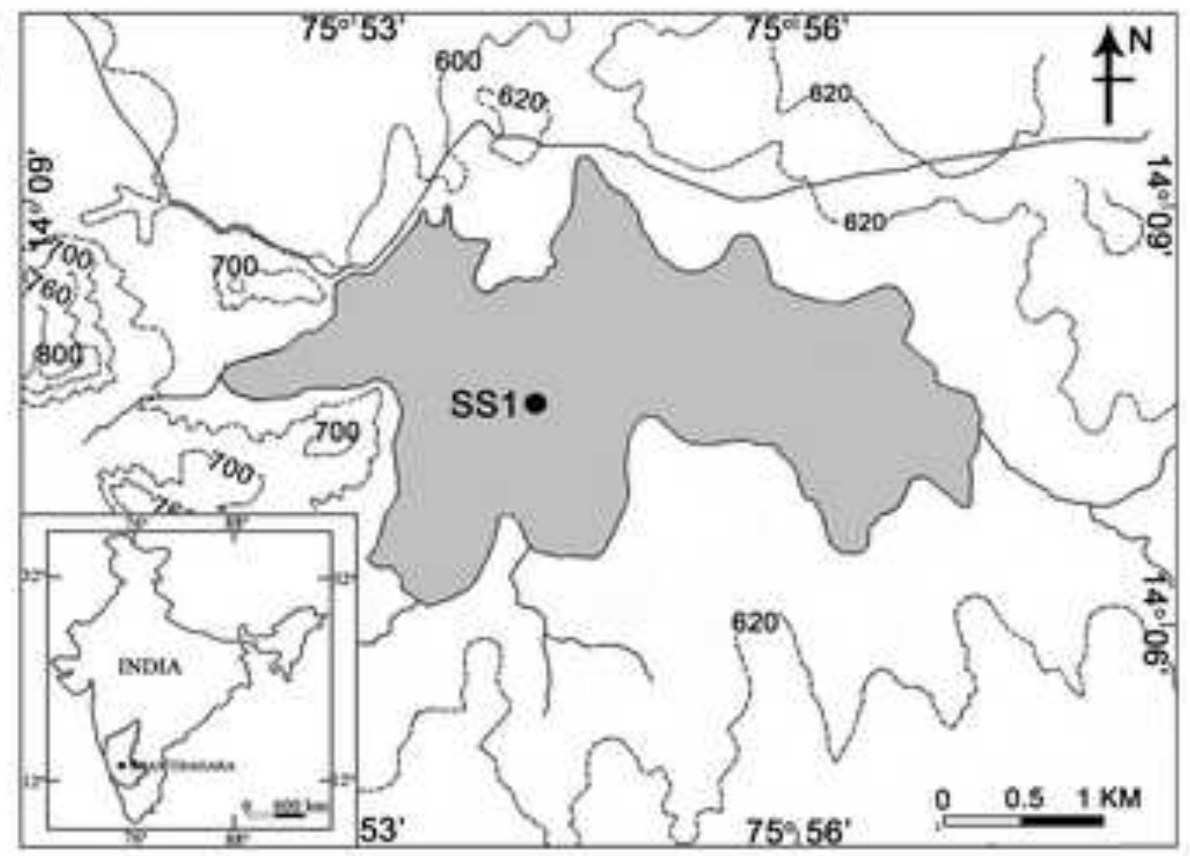

(b)

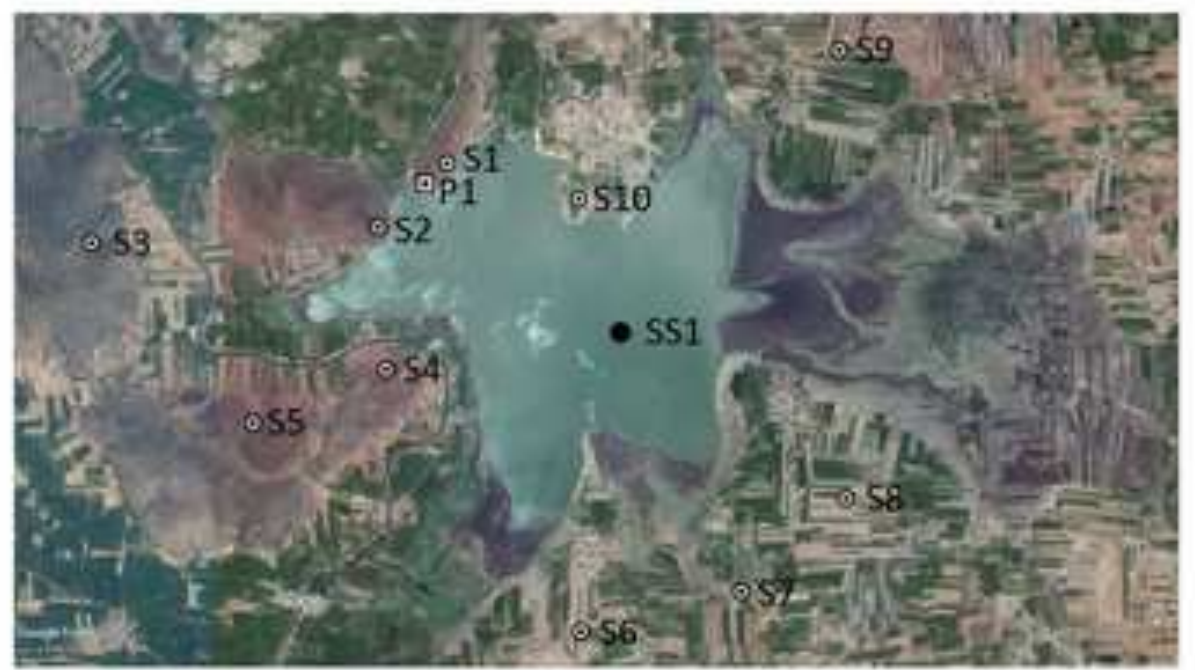

(c)

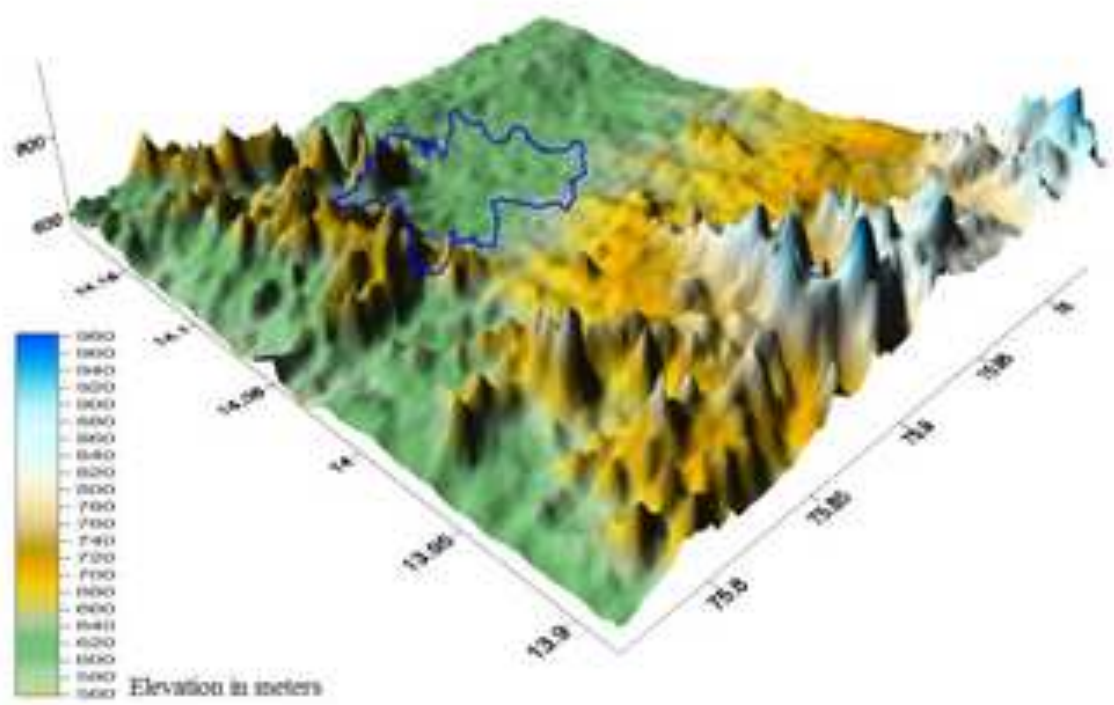




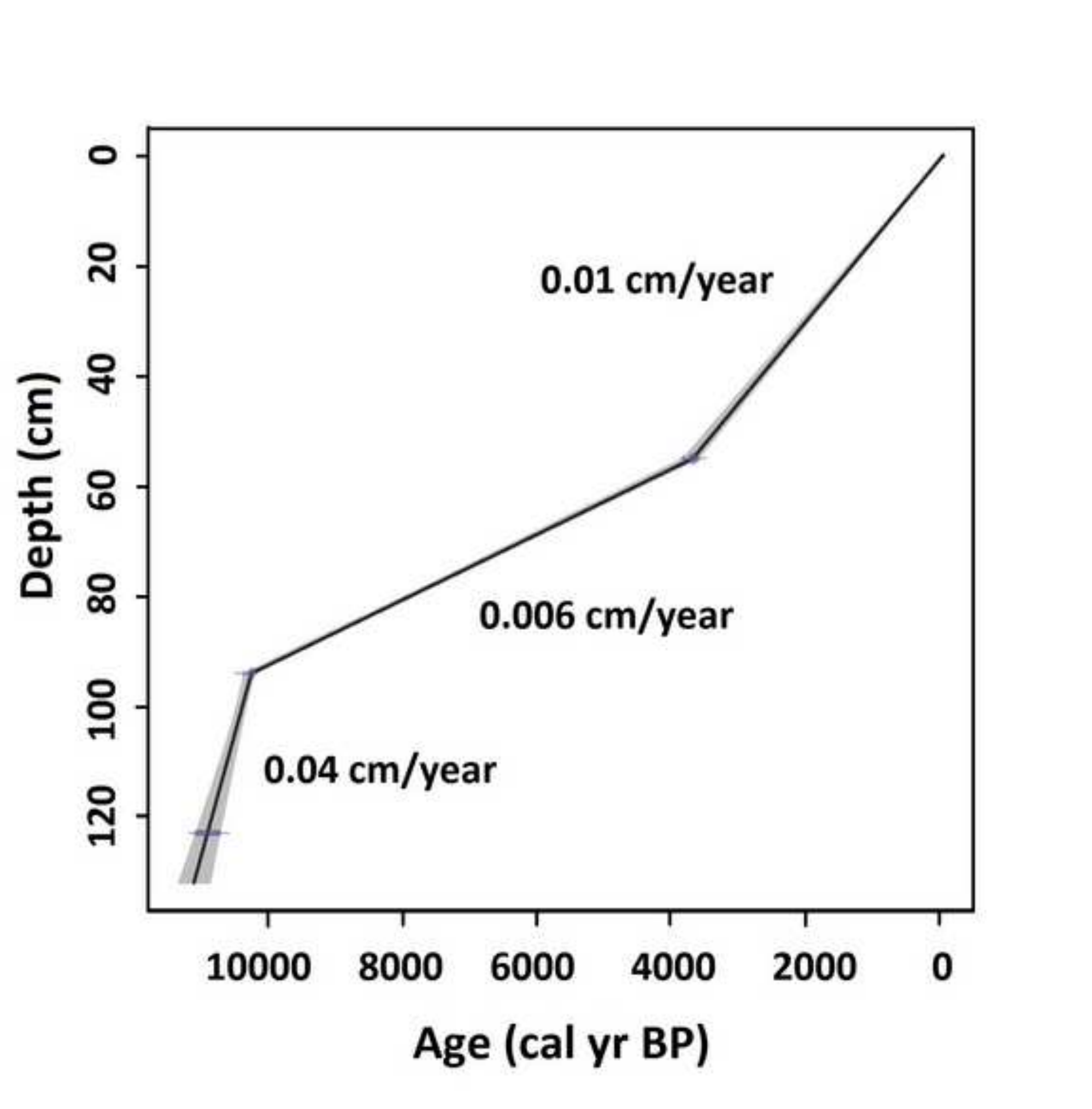

Figure 2
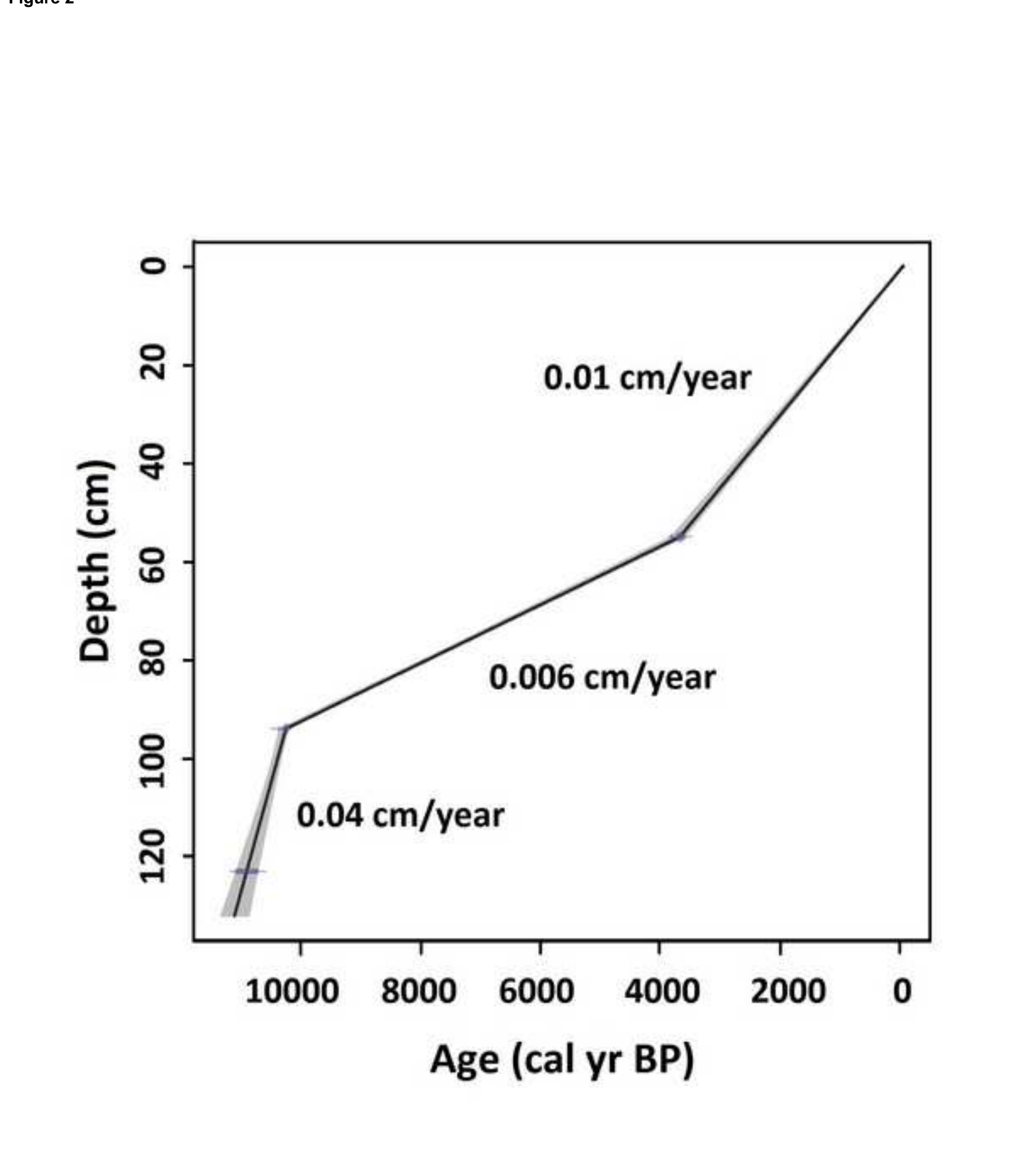

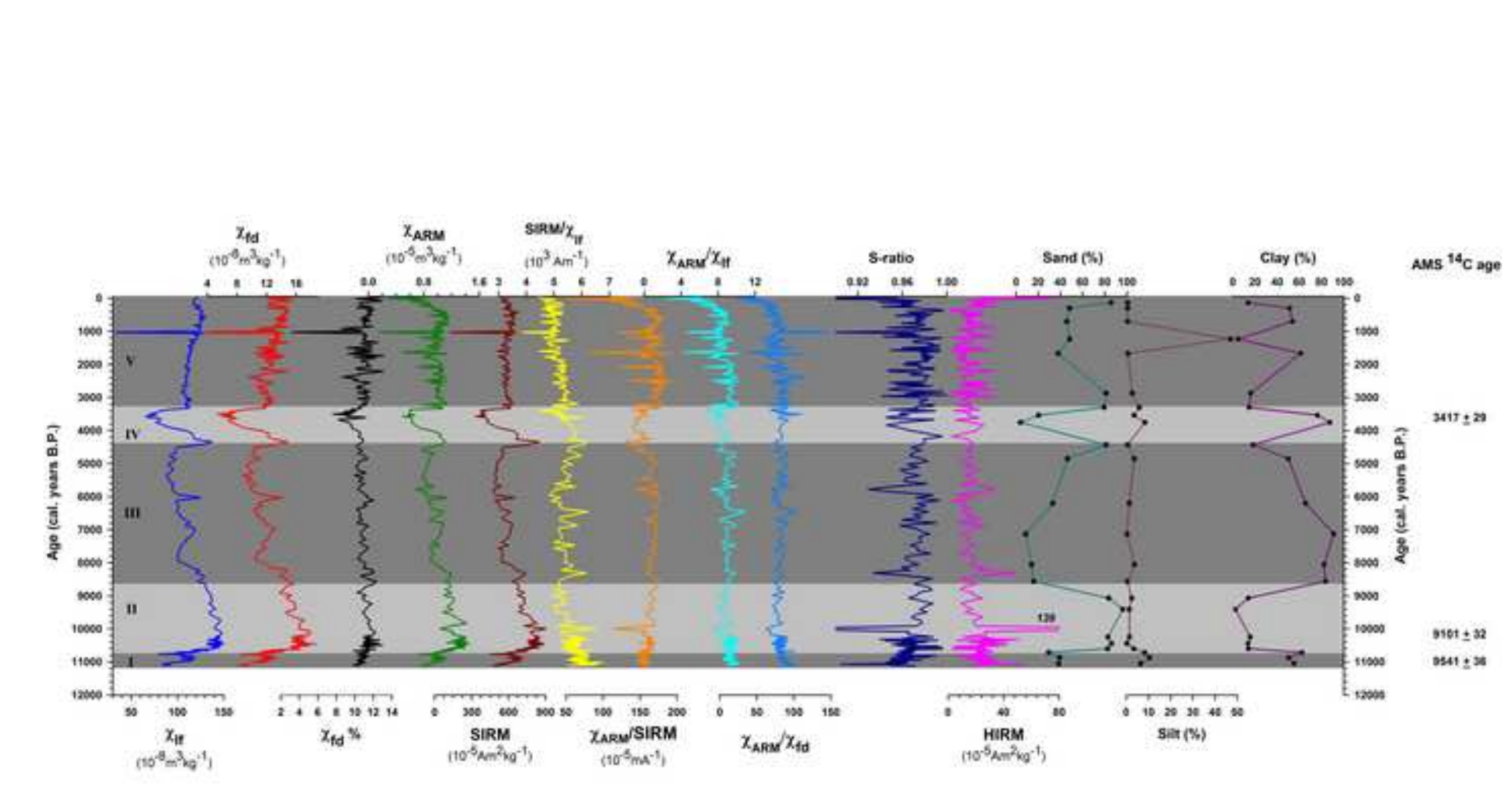

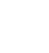

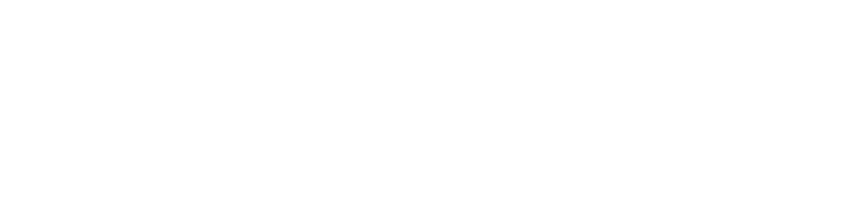



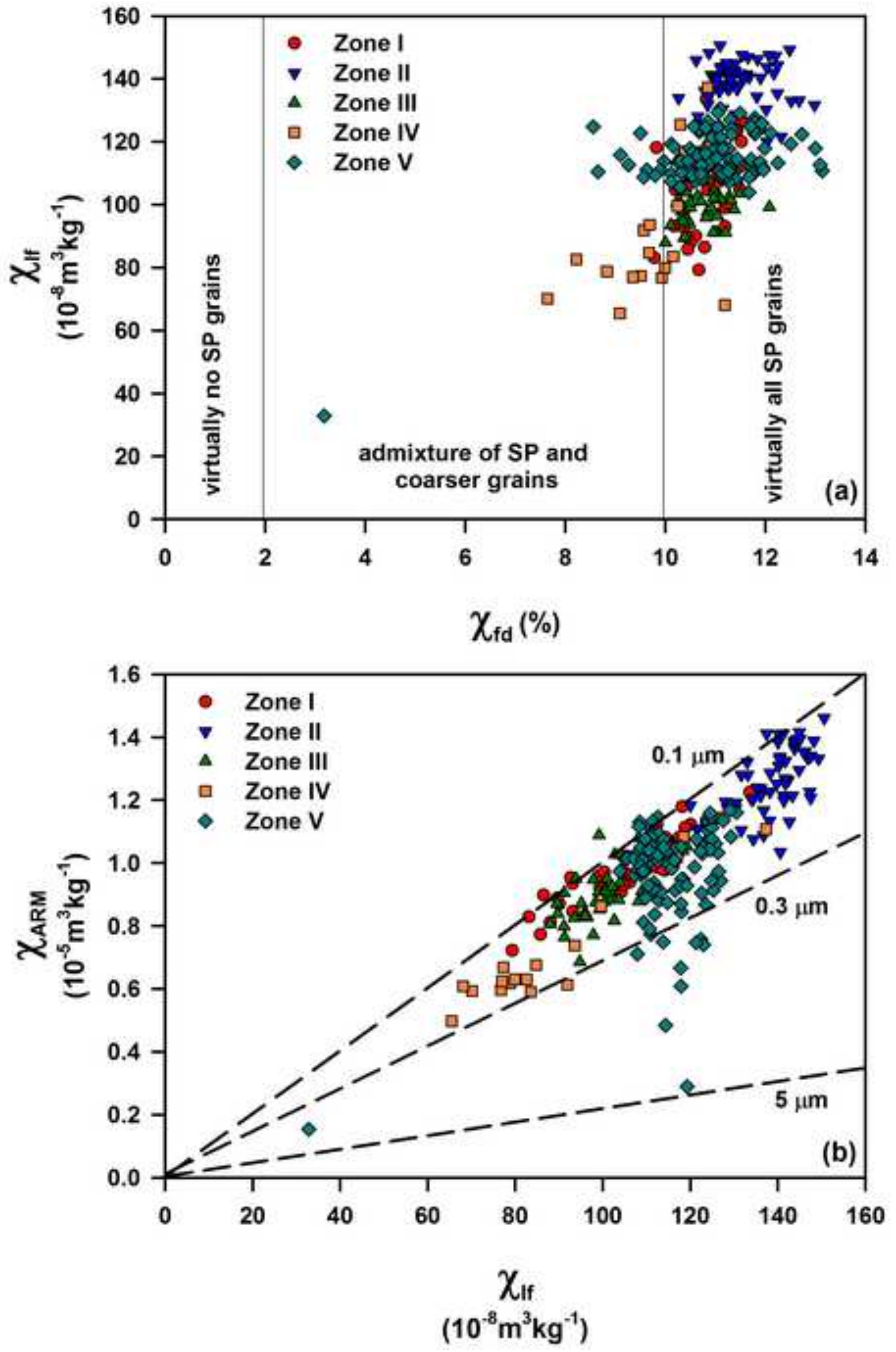


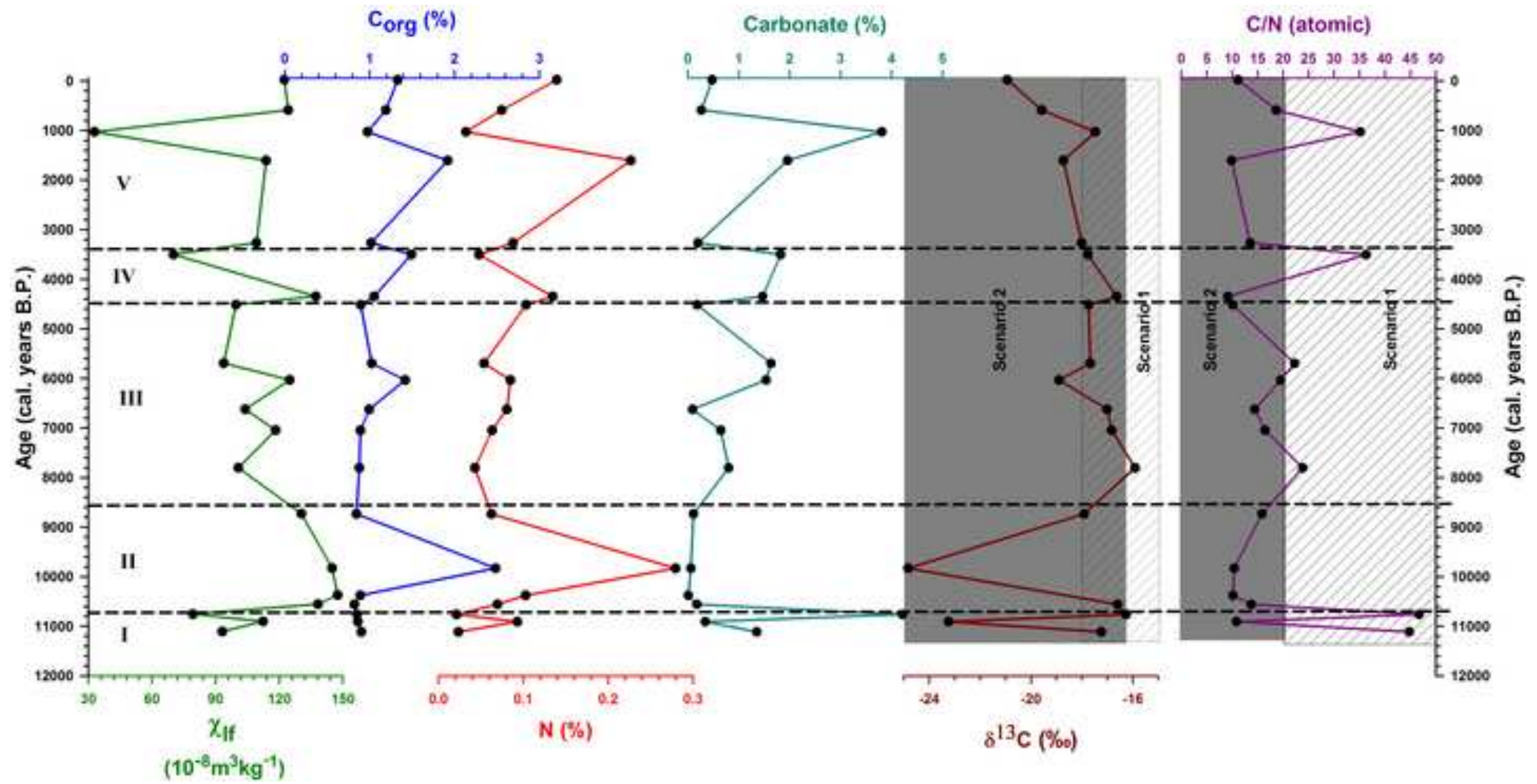



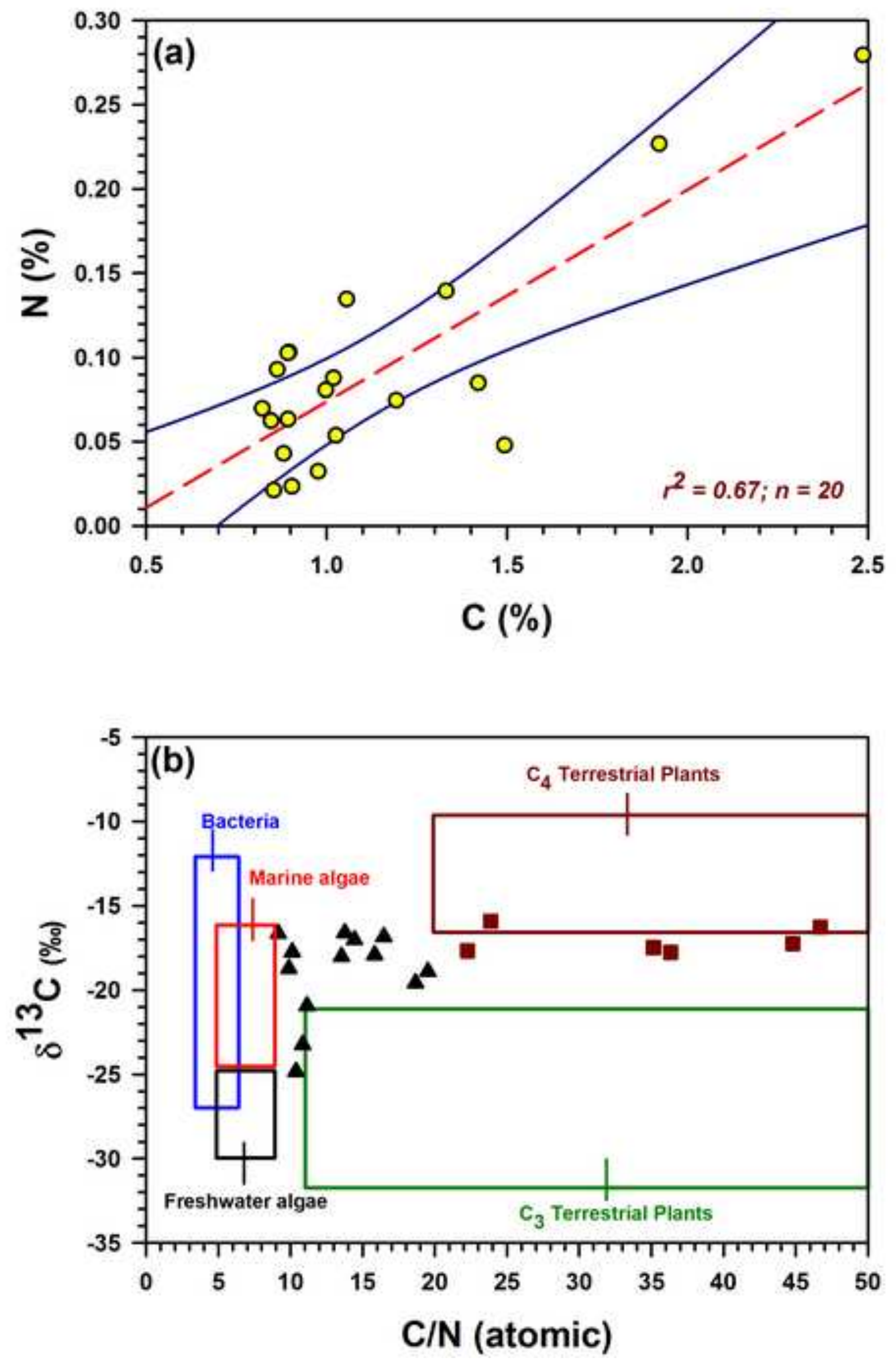

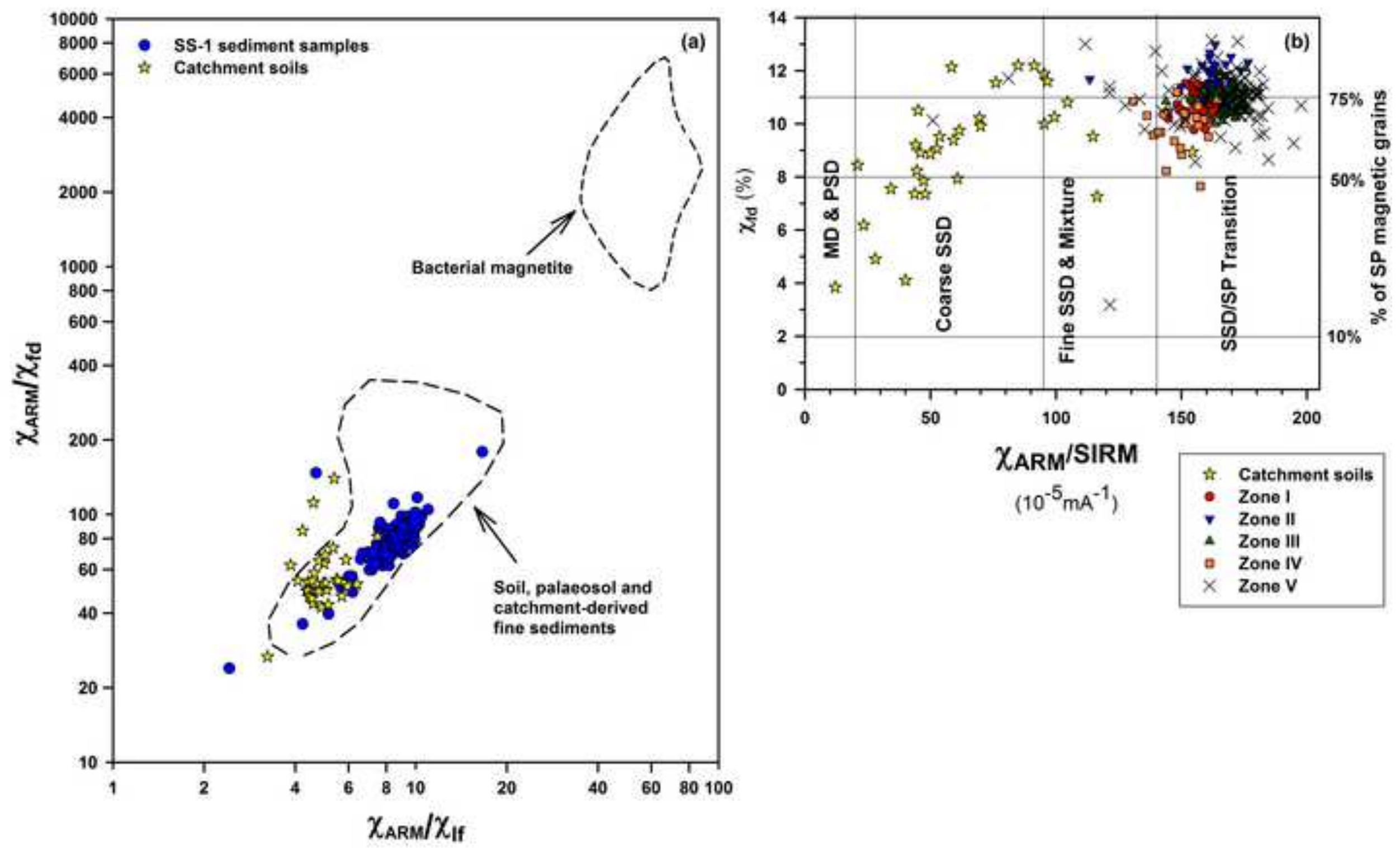


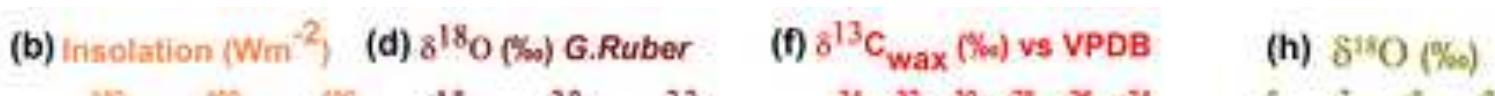

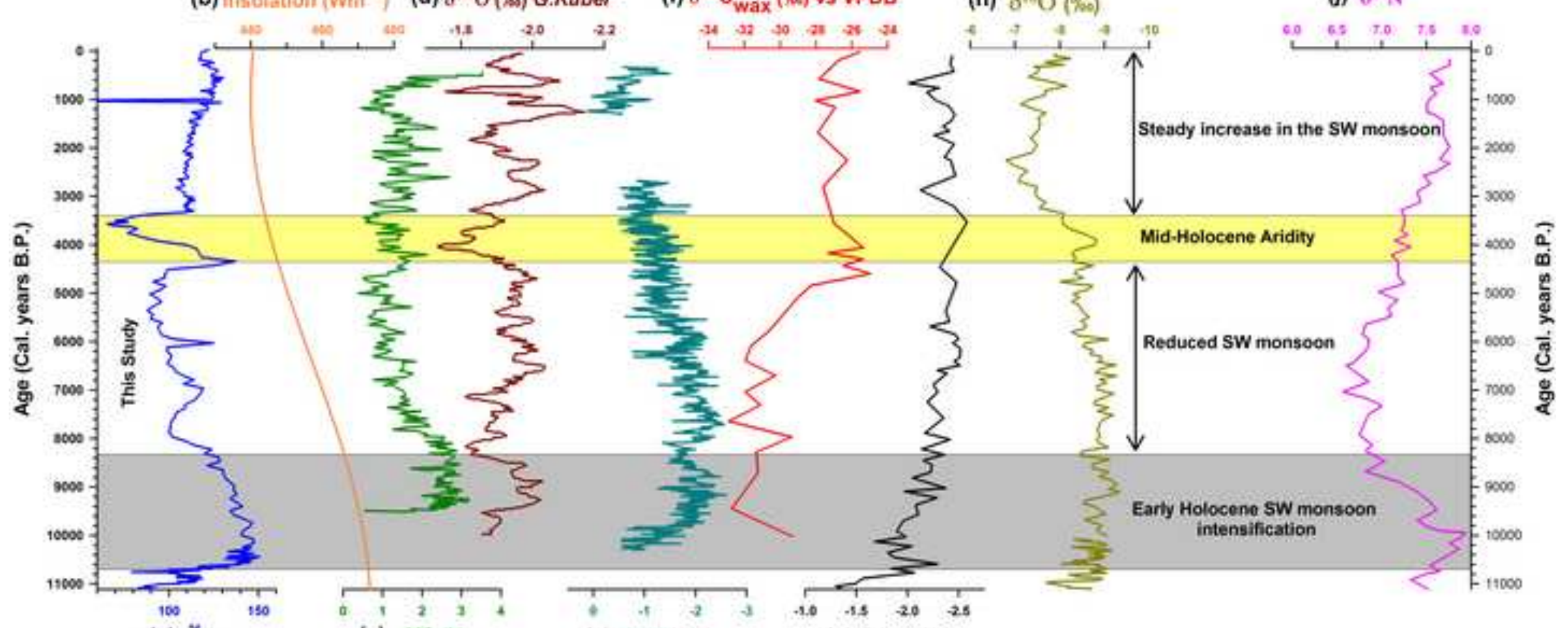

(a) $\chi_{\text {If }}$

(c) MS (k)

(e) $\delta^{18} \mathrm{O}(\%)$

(g) $8^{18} \mathrm{O}(\%)$

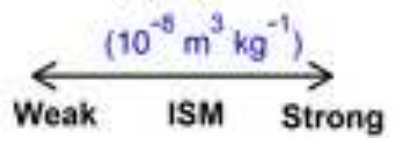

